\title{
Cloud albedo increase from carbonaceous aerosol
}

\author{
W. R. Leaitch ${ }^{1}$, U. Lohmann ${ }^{2}$, L. M. Russell ${ }^{3}$, T. Garrett ${ }^{4}$, N. C. Shantz ${ }^{1}$, D. Toom-Sauntry ${ }^{1}$, J. W. Strapp ${ }^{1}$, \\ K. L. Hayden ${ }^{1}$, J. Marshall ${ }^{5}$, M. Wolde ${ }^{6}$, D. R. Worsnop ${ }^{7}$, and J. T. Jayne ${ }^{7}$ \\ ${ }^{1}$ Environment Canada, Toronto, Ontario, M3H5T4, Canada \\ ${ }^{2}$ ETH, Zurich, Switzerland \\ ${ }^{3}$ Scripps Institution of Oceanography, University of California, San Diego, 92093, USA \\ ${ }^{4}$ University of Utah, Salt Lake City, Utah 84112-0110, USA \\ ${ }^{5}$ Max Planck Institute for Biogeochemistry, Jena, Germany \\ ${ }^{6}$ National Research Council of Canada, Ottawa, Canada \\ ${ }^{7}$ Aerodyne Research, Inc., Billerica, MA 01821-397, USA
}

Received: 20 January 2010 - Published in Atmos. Chem. Phys. Discuss.: 1 February 2010

Revised: 16 July 2010 - Accepted: 26 July 2010 - Published: 18 August 2010

\begin{abstract}
Airborne measurements from two consecutive days, analysed with the aid of an aerosol-adiabatic cloud parcel model, are used to study the effect of carbonaceous aerosol particles on the reflectivity of sunlight by water clouds. The measurements, including aerosol chemistry, aerosol microphysics, cloud microphysics, cloud gust velocities and cloud light extinction, were made below, in and above stratocumulus over the northwest Atlantic Ocean. On the first day, the history of the below-cloud fine particle aerosol was marine and the fine particle sulphate and organic carbon mass concentrations measured at cloud base were $2.4 \mu \mathrm{g} \mathrm{m}^{-3}$ and $0.9 \mu \mathrm{g} \mathrm{m}^{-3}$ respectively. On the second day, the below-cloud aerosol was continentally influenced and the fine particle sulphate and organic carbon mass concentrations were $2.3 \mu \mathrm{g} \mathrm{m}^{-3}$ and $2.6 \mu \mathrm{g} \mathrm{m}^{-3}$ respectively. Over the range $0.06-0.8 \mu \mathrm{m}$ diameter, the shapes of the below-cloud size distributions were similar on both days and the number concentrations were approximately a factor of two higher on the second day. The cloud droplet number concentrations (CDNC) on the second day were approximately three times higher than the CDNC measured on the first day. Using the parcel model to separate the influence of the differences in gust velocities, we estimate from the vertically integrated cloud light scattering measurements a $6 \%$ increase in the cloud albedo principally due to the increase in the carbonaceous components on the second day. Assuming no additional absorption by this aerosol, a $6 \%$ albedo increase translates to a local daytime radiative cooling of $\sim 12 \mathrm{~W} \mathrm{~m}^{-2}$. This re-
\end{abstract}

Correspondence to: W. R. Leaitch (richard.leaitch@ec.gc.ca) sult provides observational evidence that the role of anthropogenic carbonaceous components in the cloud albedo effect can be much larger than that of anthropogenic sulphate, as some global simulations have indicated.

\section{Introduction}

Climate prediction is challenged by uncertainties in the cooling from the effect of anthropogenic aerosol particles on the reflectivity of sunlight by water clouds. The effect is most notable for lower altitude clouds of modest thickness such as stratocumulus. This cloud albedo effect (also known as the Twomey effect and as the first indirect effect of aerosols) is rooted in the control of cloud droplet number concentrations (CDNC) by aerosol particles acting as cloud condensation nuclei (CCN) (Twomey, 1977). Twenty-nine estimates of the increase in the global radiative forcing due to the cloud albedo effect range from $-0.2 \mathrm{~W} \mathrm{~m}^{-2}$ to $-1.85 \mathrm{~W} \mathrm{~m}^{-2}$ (Forster et al., 2007), underscoring the significance of this effect and the uncertainty in its prediction. Scaling of general circulation models with satellite data suggests the cloud albedo effect can be constrained as $-0.7 \pm 0.5 \mathrm{~W} \mathrm{~m}^{-2}$ (Quaas et al., 2009) and an estimate based on an energy balance approach is consistent with that result (Murphy et al., 2009).

Anthropogenic sources of carbonaceous and sulphate compounds increase the number and mass concentrations of atmospheric aerosol particles and CCN. As a major constituent of the global fine particle aerosol, sulphate components are believed to contribute significantly to the cloud albedo effect due in large part to their relatively

Published by Copernicus Publications on behalf of the European Geosciences Union. 
high hygroscopicity. Carbonaceous components are also ubiquitous constituents of the global fine particle aerosol (Zhang et al., 2007; Bahadur et al., 2009). Since Novakov and Penner (1993) demonstrated a connection between carbonaceous particles and $\mathrm{CCN}$, many observations have indicated varying degrees of effectiveness of the carbonaceous components at water uptake. Typically carbonaceous components are much less hygroscopic than sulphate components (e.g. McFiggans et al., 2006; Petters and Kreidenweis, 2007) and their effects on CDNC and cloud albedo are highly uncertain. In the absence of significant water activity of the carbonaceous aerosol, a relatively small fraction of sulphate in a particle can influence the ability of the mixed sulphatecarbonaceous particle to act as a CCN (e.g. Lohmann et al., 2004; Petters et al., 2006; King et al., 2007; Prenni et al., 2007). How carbonaceous particles contribute to the aerosol number distribution may represent their most significant $\mathrm{CCN}$ influence, since the number distribution is important for the number of CCN (e.g. Russell et al., 1999; Roberts et al., 2002; Dusek et al., 2006; Pierce et al., 2007) and potentially the CDNC (e.g. Conant et al., 2004; Meskhidze et al., 2005; McFiggans et al., 2006). Fountoukis et al. (2007) explicitly considered the role of the carbonaceous aerosol in the nucleation of cloud droplets and found limited sensitivity of their CDNC-aerosol closure study to the solubility of organic mass (OM). On the other hand, ambient $\mathrm{CCN}$ observations indicate that the hygroscopicity of the carbonaceous components takes on greater relative importance as the fraction of sulphate is reduced (e.g. Roberts et al., 2002; Ming and Russell, 2004; Chang et al., 2007; Prenni et al., 2007; Wang et al., 2008; Gunthe et al., 2009), and Wex et al. (2009) found an increase in the hygroscopicity of secondary carbonaceous components with increasing aerosol water content. Thus, there will be situations for which the typically lower hygroscopicity of carbonaceous aerosols has a significant influence on the droplet growth rates.

The possibility of carbonaceous material, in the form of organic films, impeding water condensation and effectively lowering the mass accommodation coefficient for water vapour condensing on the growing droplets $\left(\alpha_{\mathrm{c}}\right)$ has been considered for several years (e.g. Penner et al., 2001). As droplets grow, albeit more slowly, such films are likely to break, thus removing the impedance to water uptake (e.g. Feingold and Chuang, 2002). Johnson et al. (2005) found that volatilization of a low solubility organic that may have coated particles resulted in an increase in their water uptake rate suggesting suppression by an organic material. Kinetic inhibition has also been observed with some anthropogenic aerosols (Ruehl et al., 2008, 2009; Shantz et al., 2010). Shantz et al. (2010) found that values of $\alpha_{\mathrm{c}}$ for concentrated solution droplets needed to be in the range 0.04 0.07 in order to explain observed rates of water uptake by anthropogenic particles. As droplets dilute and the situation approaches water on water condensation, a value of unity is appropriate for $\alpha_{\mathrm{c}}$ (Wagner et al., 1982; Mozurkewich, 1986;
Davidovits et al., 2004; Laaksonen et al., 2005). Particularly with field observations, the effects of mass accommodation, surface tension and other physical-chemical properties of the carbonaceous aerosol are not always easily distinguished.

Global simulations of the indirect effect have begun to move away from empirical prediction of CDNC based on a parameterization of sulphate as a surrogate towards the explicit representation of the major global aerosol components. These mechanistic approaches are required for long range prediction; although they have not yet reduced the uncertainty range of the indirect aerosol effect because the aerosol components and their size distributions introduce new uncertainties (Menon et al., 2003; Penner et al., 2006; Lohmann, 2007; Pringle et al., 2009). Some studies that have used mechanistic treatments of the carbonaceous and sulphate aerosols have attributed more radiative cooling via the cloud albedo effect to the carbonaceous aerosol than to the sulphate aerosol. Lohmann et al. (2000) found that the change in the radiative cooling by the cloud albedo effect between present-day and pre-industrial time ranged from near zero to $-0.4 \mathrm{~W} \mathrm{~m}^{-2}$ due to anthropogenic sulphate and $-0.9 \mathrm{~W} \mathrm{~m}^{-2}$ to $-1.3 \mathrm{~W} \mathrm{~m}^{-2}$ due to anthropogenic carbonaceous aerosol. The reduced effect of the sulphate aerosol relative to the carbonaceous aerosol was a combination of a larger increase in the carbonaceous burden and a larger mode radius of the sulphate. Chuang et al. (2002) estimated a global cloud albedo effect of $-1.85 \mathrm{~W} \mathrm{~m}^{-2}$, of which $-0.30 \mathrm{~W} \mathrm{~m}^{-2}$ was associated with anthropogenic sulphate, $-1.16 \mathrm{~W} \mathrm{~m}^{-2}$ was associated with carbonaceous aerosols from biomass burning, and $-0.52 \mathrm{~W} \mathrm{~m}^{-2}$ was associated with carbonaceous aerosols from fossil fuel combustion; the total forcing does not equal the sum of the individuals because of the nonlinear relationship between CDNC and aerosol number concentrations. Together, these two studies suggest that the impact on cloud albedo by the carbonaceous aerosol is 3-6 times that due to the sulphate. On the other hand, Ghan et al. (2001) found their mechanistic model indicated the cloud albedo effect was dominated by sulphate.

Here, we present observational evidence to show that the carbonaceous aerosol can indeed enhance the cloud albedo effect as suggested by Lohmann et al. (2000) and Chuang et al. (2002). We contrast airborne observations of aerosol and cloud properties from two flights on back-to-back days over the Atlantic Ocean. These cases are unique in two ways. First, the trajectories suggest a marine character to the aerosol on the first day and a continental/anthropogenic composition to the aerosol on the second day. Second, the number size distribution of the cloud base aerosol sampled on the second day is similar in shape over the range of 0.06$0.8 \mu \mathrm{m}$ diameter and approximately twice the concentration of that sampled on the first day. The increase in the size distribution is associated with an increase in the submicron carbonaceous aerosol mass concentration relative to the submicron sulphate aerosol mass concentration and the increase is reflected in the observed CDNC and cloud light scattering. 

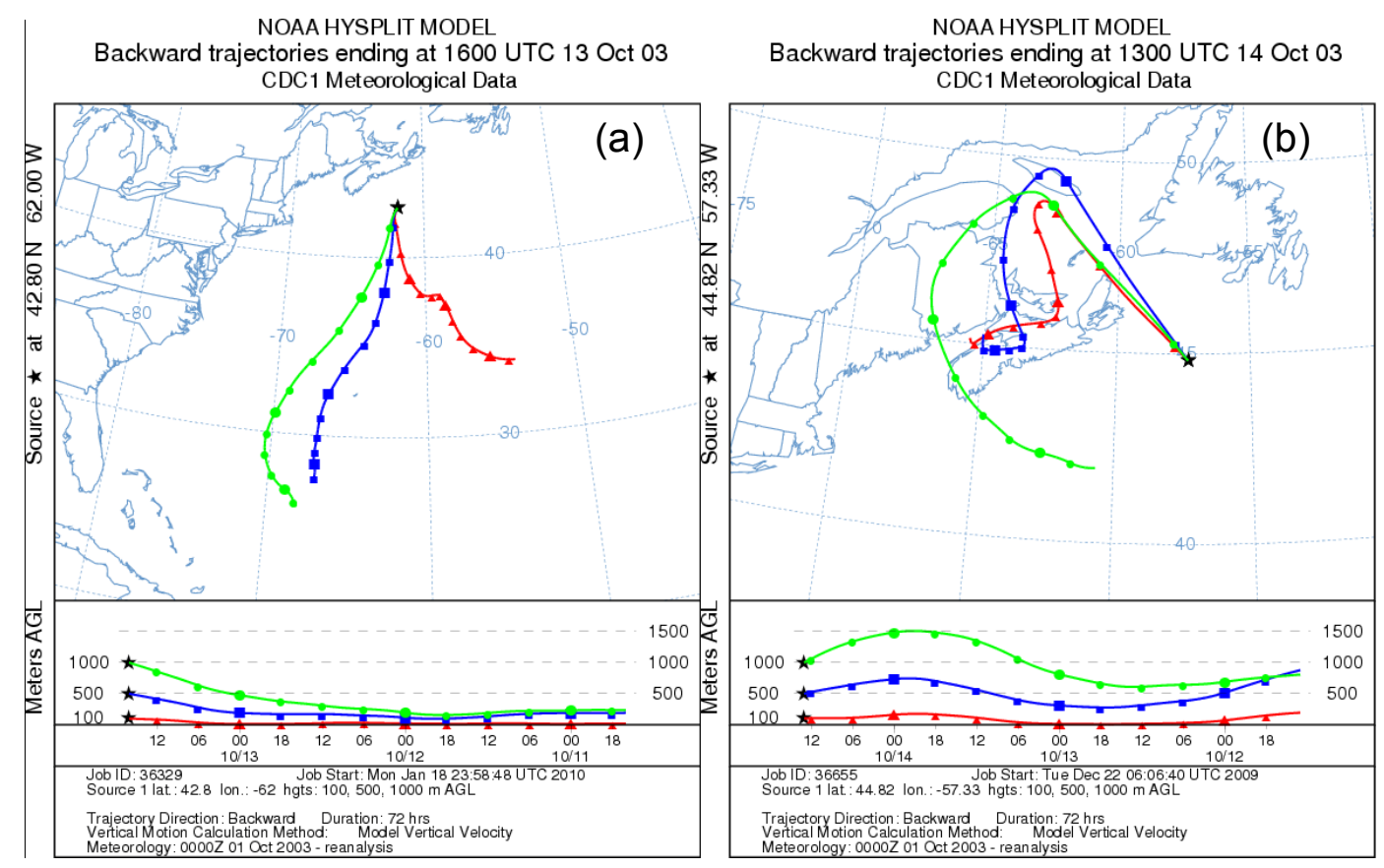

Fig. 1. Meteorological 3-day back trajectories (Draxler, R. R. and Rolph, G. D., 2003; Rolph, 2003) for end points at the approximate time and location of vertical profiles through the clouds: (a) flight 1; (b) flight 2.

\section{Experimental}

\subsection{Overview}

The measurement platform was the National Research Council of Canada Convair 580 aircraft. The two flights considered here were conducted in and around stratocumulus on 13 October 2003 and 14 October 2003 within a few hundred kilometers east of Nova Scotia; hereafter referred to as flights 1 and 2 respectively. The flights were part of the Canadian SOLAS program. Profile data from flights 1 and 2 were collected near $42^{\circ} 48^{\prime} \mathrm{N}, 62^{\circ} \mathrm{W}$ and $44^{\circ} 50^{\prime} \mathrm{N}, 57^{\circ} 20^{\prime} \mathrm{W}$ respectively. The meteorological back trajectory analyses from the NOAA HYSPLIT model (Draxler and Rolph, 2003; Rolph, 2003) indicate that the aerosol sampled during flight 1 had resided over the Atlantic Ocean to the south-southwest of the sampling area for three days prior to observation (Fig. 1a). The trajectory analysis for flight 2 indicates a significant continental influence to the aerosol (Fig. 1b).

\subsection{Instrumentation}

Relevant measurements and the corresponding instrumentation are outlined in Table 1.

Comprehensive descriptions of the Aerodyne Quadruple Aerosol Mass Spectrometer (Q-AMS) are found elsewhere (Jayne et al., 2000; Jimenez et al., 2003). The Q-AMS was used to measure the average mass concentration and size distributions of non-refractory particulate species every 5-min; 5-min averages were chosen to optimize the signal-to-noise versus the spatial resolution. The temperature of the vaporizer in the AMS, used to volatilize the particles into molecular fragments, was set to about $550{ }^{\circ} \mathrm{C}$ enabling the measurement of components such as ammonium sulphate and many organics, but not sodium chloride. The transmission of particles into the AMS is approximately $100 \%$ in the range $0.1-0.7 \mu \mathrm{m}$ vacuum aerodynamic diameter $\left(D_{\mathrm{va}}\right)$, decreasing sharply outside that range (Liu et al., 2007); the upper transmission limit for this particular AMS has been demonstrated (Rupakheti et al., 2005). The collection efficiency of particles by the oven is assumed to be $100 \%$ for this dataset. This assumption is based on the comparison of the sulphate mass concentrations from the Q-AMS with those from the ParticleIn-Liquid-Sampler (PILS; described below), and it is consistent with previous results with this Q-AMS (Rupakheti et al., 2005; Buset et al., 2006; Phinney et al., 2006; Langley et al., 2010); more acidic sulphate, as here, is efficiently sampled. Analysis of AMS data was performed using the Deluxe 1.29 IGOR data analysis package (Allan et al., 2003) with a batch file (used for quantitative calibration) and fragmentation file (used for identification of chemical species present on the aerosol) customized to this data set. The fragmentation file included methanesulphonic acid (Langley et al., 2010), but MSA was not found to be significant in these observations.

Aerosol particles were collected in water using a PILS and analyzed for their major water soluble inorganic chemical components onboard with two ion chromatographs (IC). The PILS collection system is described briefly here, and 
Table 1. Instrumentation list.

\begin{tabular}{|c|c|}
\hline Measurement & Instrument \\
\hline Aerosol particle number and size & $\begin{array}{l}\text { TSI SMPS }(10-500 \mathrm{~nm})-\text { inboard }-2.5 \text { min averages } \\
\text { PMS PCASP100X }(0.14-3 \mu \mathrm{m})-\text { outboard under wing }-1 \mathrm{~s} \text { ave. } \\
\text { TSI APS } 3321(0.54-20 \mu \mathrm{m})-\text { inboard }-1 \text { min ave. } \\
\text { PMS FSSP } 300(0.5-20 \mu \mathrm{m}) \text { - outboard under wing }-1 \mathrm{~s} \text { ave. }\end{array}$ \\
\hline Cloud droplet number and size & 2 PMS FSSP100 $(2-45 \mu \mathrm{m})-$ outboard under wing $-1 \mathrm{~s}$ ave. \\
\hline Cloud liquid water content & PMS King Probe - outboard under wing - $1 \mathrm{~s}$ ave. \\
\hline Cloud light Extinction & $\begin{array}{l}\text { Gerber Cloud Integrating Nephelometer }(\mathrm{CIN}) \text { - outboard under wing } \\
-1 \mathrm{~s} \text { ave. }\end{array}$ \\
\hline Aerosol particle chemistry & $\begin{array}{l}\text { Aerodyne Quadrapole Mass Spectrometer (Q-AMS) - inboard - } \\
5 \text { min ave. } \\
\text { Particle-In-Liquid sampler (PILS) with Dionex ICS } 2000 \text { Ion } \\
\text { Chromatographs - inboard - } 10 \text { min averages }\end{array}$ \\
\hline
\end{tabular}

it is similar to that described by Orsini et al. (2003); this particular PILS has been previously documented (Buset et al., 2006). Briefly, the system used two Dionex Ion Chromatographs (ICS 2000) with eluent generation, temperature control and degassing for anions and cations. The anions and cations were eluted in $25 \mathrm{mM}$ Potassium Hydroxide and $25 \mathrm{mM}$ Methanesulfonic Acid respectively. Trace gases were denuded from the aerosol prior to entering the PILS, where the particles are grown to supermicron size droplets under supersaturated conditions created by mixing the sample air with steam. Particles larger than $0.03 \mu \mathrm{m}$ diameter that enter the PILS are activated with a $>97 \%$ collection efficiency at a sample flow rate of $151 \mathrm{~m}^{-1}$ as used here. The droplets are impacted onto a surface that is washed off with a steady stream of de-ionized water. The water is delivered to trace concentrator columns of the IC for analysis. Samples were averaged for $10 \mathrm{~min}$.

Four instruments were used to measure the size distributions of the aerosol particles. A TSI Scanning Mobility Particle System (SMPS) with a TSI 3010 Condensation Particle Counter (CPC) was used to measure particles from $10 \mathrm{~nm}$ to $500 \mathrm{~nm}$ geometric diameter $\left(D_{\mathrm{g}}\right)$. A TSI Aerodynamic Particle Sizer (APS) was used to measure particles from $0.6 \mu \mathrm{m}$ to $20 \mu \mathrm{m}$ aerodynamic diameter $\left(D_{\mathrm{a}}\right)$. Both the SMPS and APS were located inboard the aircraft. Two Particle Measuring Systems (PMS) probes, a Passive Cavity Aerosol Spectrometer Probe (PCASP100x) and a Forward Scattering Spectrometer Probe (FSSP300), were used to measure particles from $0.14 \mu \mathrm{m}$ to $1 \mu \mathrm{m} D_{\mathrm{g}}$ and from $0.3 \mu \mathrm{m}$ to $20 \mu \mathrm{m} D_{\mathrm{g}}$, respectively. The PCASP100x and the FSSP300 were suspended from a pylon under a wing of the aircraft. The FSSP is a non-intrusive probe and the particle sizing includes any water that the particles retain. The other three instruments (SMPS,
APS and PCASP) are assumed to have measured the nearly dry sizes of the particles due to internal heating (PCASP), the slight warming of air as it entered the aircraft from outside (SMPS and APS) and dried sheath air used (all three). A comparison of this PCASP100x and FSSP300 is discussed by Strapp et al. (1992). We use the $1 \mathrm{~Hz}$ observations from the PCASP to illustrate the changes of particle number concentrations in the profiles as well as the variability during level flight below cloud base. The number concentrations from the PCASP and those from the SMPS for $>140 \mathrm{~nm}$ agree to within $20 \%$. We do not include the PCASP measurements in the size distributions because the optical sizing is more uncertain. We also note that differences between optical sizing and mobility sizing have been shown to affect the calculated CDNC (Snider et al., 2003).

A shrouded nearly isokinetic diffuser set $15 \mathrm{~cm}$ off the starboard side of the fuselage ahead of the engine was used to bring the aerosol into the cabin. From there, the aerosol was carried by $1 \mathrm{~cm}$ OD stainless steel tubing to the SMPS, APS, AMS and PILS. The distance from the intake point to the SMPS and APS was about $1 \mathrm{~m}$ and about $5 \mathrm{~m}$ to the AMS and PILS. Agreement between the APS and FSSP300 size distributions was reasonable in the overlap region below $1 \mu \mathrm{m}$. Above $1 \mu \mathrm{m}$, the particle concentrations measured with the APS were significantly lower than the FSSP300 (Fig. 2a; the APS aerodynamic diameters were converted to geometric diameter assuming spherical particles and a density of $1.5 \mathrm{~g} \mathrm{~cm}^{-3}$ ). Drying of the particles may contribute to some of the discrepancy above $1 \mu \mathrm{m}$, but this result indicates that losses in the inlet were only significant for particles $>1 \mu \mathrm{m}$. The measurements from the FSSP300 are used to define the size distribution for particles $>0.9 \mu \mathrm{m}$. We do not adjust the FSSP300 measurements for water on the particles; 

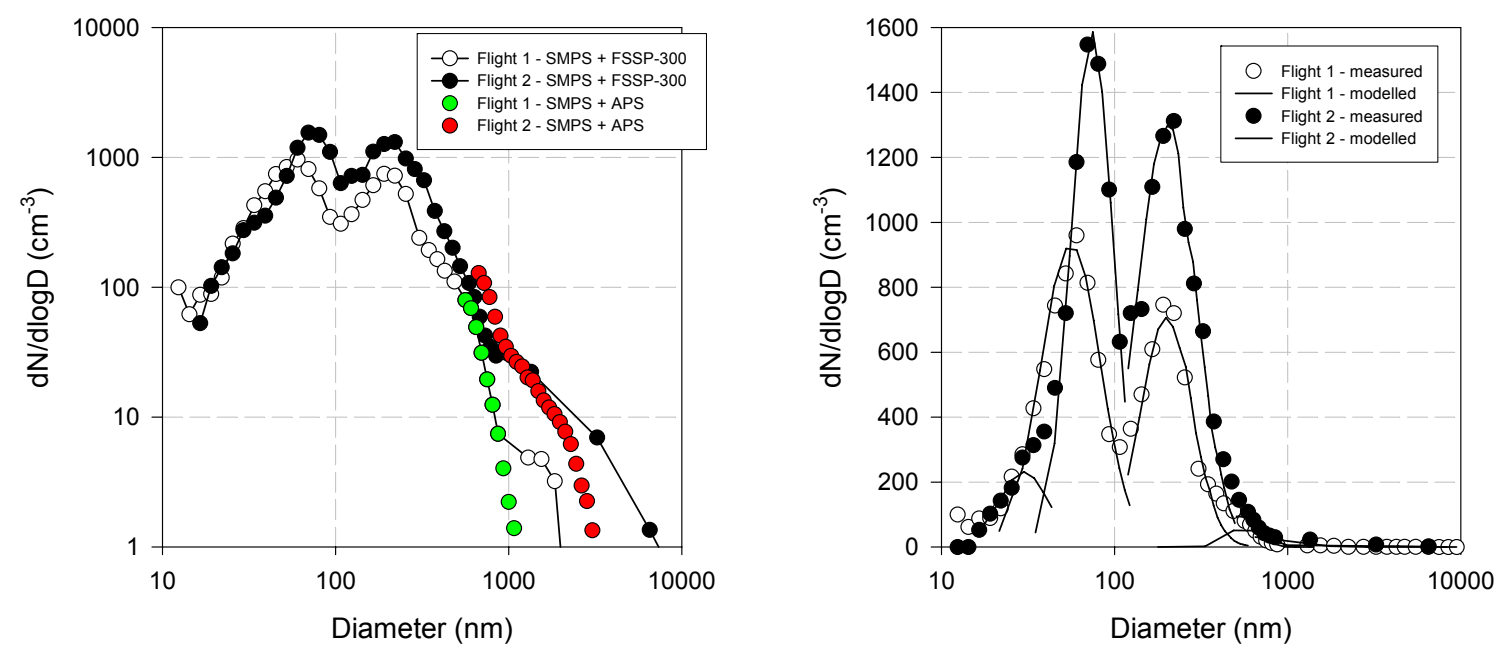

Fig. 2. (a) Size distributions combining data from the Scanning Mobility Particle System (SMPS; 10-400 nm) and the outboard Forward Scattering Spectrometer Probe for coarse aerosol particles (FSSP300; 300-20000 nm) as well as data from the inboard Aerodynamic Particle Sizer distributions (APS; sizes converted to a geometric diameter assuming a density of $1.5 \mathrm{~g} \mathrm{~cm}^{-3}$ ). Divergence of the FSSP300 and APS above $1 \mu \mathrm{m}$ is believed to be mostly due to losses at the aircraft intake. (b) Modeled fits to the measured size distributions; details given in Table 5. For (b), we use the SMPS, the APS up to $900 \mathrm{~nm}$ and the FSSP300 above $900 \mathrm{~nm}$.

a. (Flight 1 LWC)

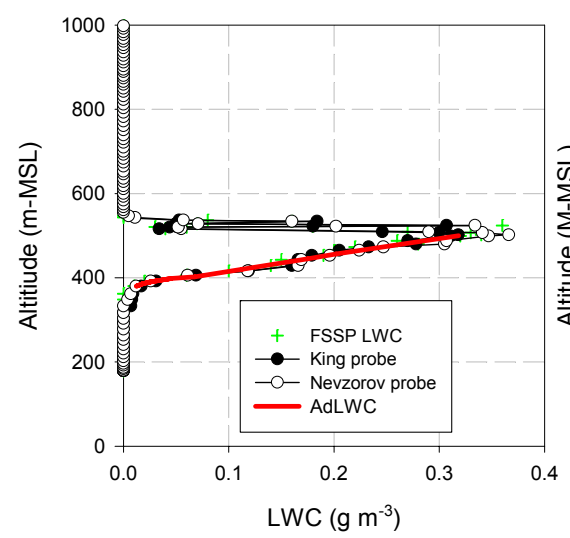

b. (Flight 2 LWC)

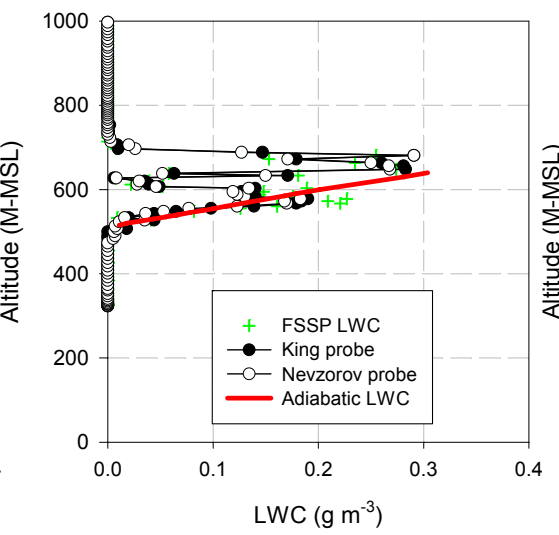

c. (Flights 1 and 2 Extinction)

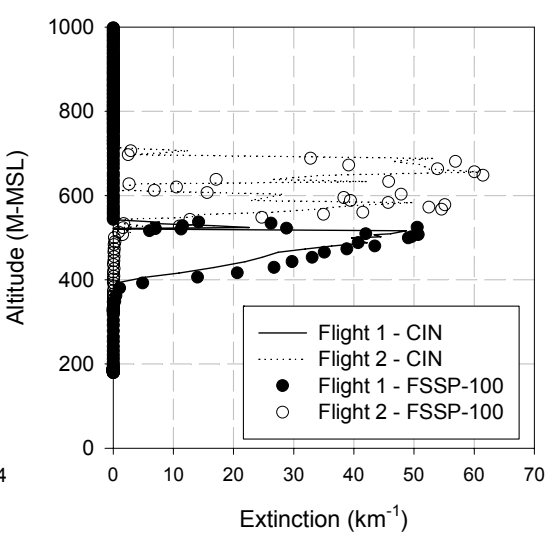

Fig. 3. For flights 1 (a) and 2 (b), vertical profiles of cloud liquid water content (LWC) from three independent measurements (PMS King probe, Nevzorov probe and PMS FSSP100 integrated droplet size distribution) plus the adiabatic LWC. The adiabatic profiles are from the model calculations. The King probe are used elsewhere in the paper. Profiles of cloud light extinction coefficient for flights 1 and 2 (c) from the Gerber Cloud Integrating Nephelometer (CIN) and calculated from the PMS FSSP100 droplet size distributions.

the relative humidities measured during level sampling below cloud were $83 \%$ and $85 \%$ for flights 1 and 2 respectively. We note that the accuracy of the coarse particle measurements is not a significant concern for the present study, but it can be important when considering giant $\mathrm{CCN}$ that may influence precipitation formation.

Cloud liquid water contents (LWC) were measured using a PMS King LWC probe and a Nevzorov LWC probe deployed from a pylon suspended from a wing; comparison of the LWC measurements is shown in Fig. 3. The LWC is measured to within $15 \%$ and the baseline drift is estimated to be
$<0.02 \mathrm{~g} \mathrm{~m}^{-3}$ (Cober et al., 2001). Correction factors applied for the effects of flow around the aircraft were between 1.03 and 1.05 (Cober et al., 2001; Drummond and MacPherson, 1985).

Two PMS FSSP100 probes, also suspended from a pylon under a wing, were used to measure the cloud droplet number size distribution and covered the size range of $2-47 \mu \mathrm{m}$. Their sample volumes are based on the measured sample area of the probe and the measured airspeed. Sizing calibrations, corrected to the index of refraction of water, were done with glass beads. The data are $1 \mathrm{~s}$ average values, representing a 
a. Flight 1

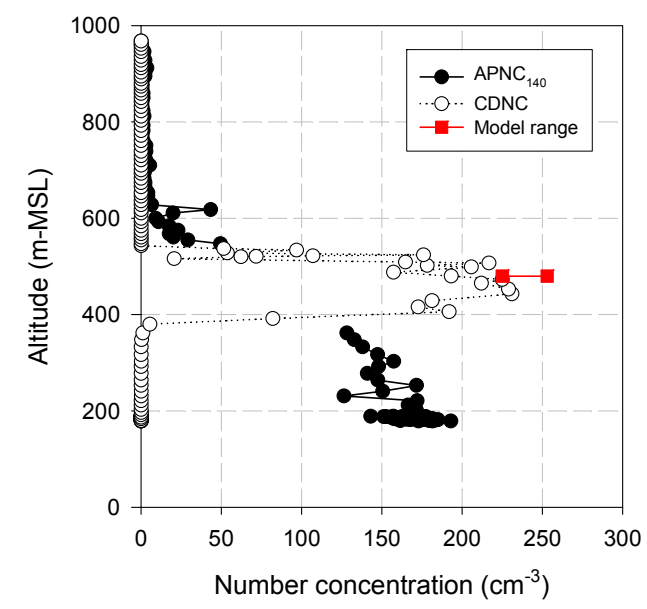

b. Flight 2

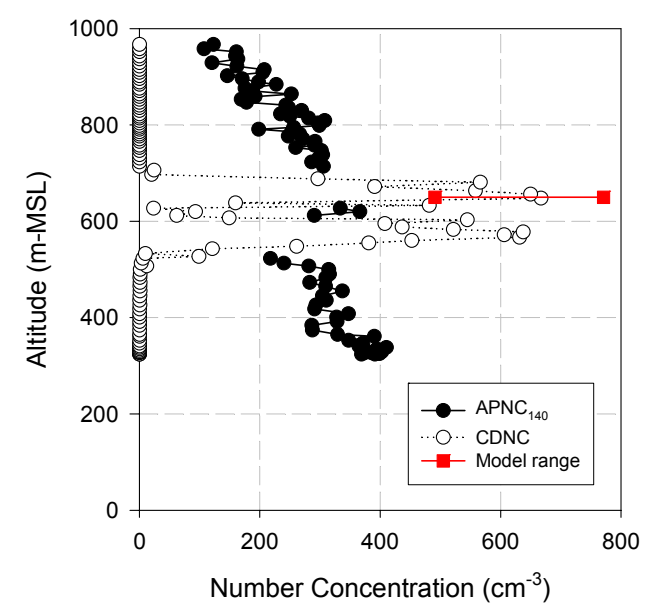

Fig. 4. Vertical profiles of APNC140 and CDNC through cloud during flight 1 (a) and flight 2 (b).

Table 2. Simple statistics of one second observations of the $\mathrm{APNC}_{140}$ (units of $\mathrm{cm}^{-3}$ ) under cloud base for flights 1 and 2 . Thirteen minutes were spent directly under cloud base during flight 1 and 6 minutes during flight 2 . These periods are also those used to define the chemistry of the cloud base aerosol as given in Table 3.

\begin{tabular}{lll}
\hline Statistic & Flight 1-13 Oct 2003 & Flight 2-14 Oct 2003 \\
\hline & $19: 07-19: 21$ UT & $12: 36-12: 42$ UT \\
Mean & 166 & 393 \\
Median & 166 & 393 \\
Std Dev & 13.8 & 32 \\
$>99 \%$ & $166 \pm 42$ & $393 \pm 96$ \\
Range & $124-208$ & $297-489$ \\
\hline
\end{tabular}

sampling path length of 90-100 m. The cloud droplet number concentrations (CDNC) were corrected for coincidence error and probe dead time (Baumgardner et al., 1985). Corrections of the FSSP100 data for flow around the aircraft were not taken into account because the effects of flow on the measurements (ca. 2\%) were significantly less than the probe measurement accuracies for the $\mathrm{CDNC}( \pm 15 \%)$ (Cober et al., 2001).

Measurements of the cloud scattering coefficient were made using a Gerber Scientific Inc. Cloud Integrating Nephelometer (CIN; Gerber et al., 2000; Garrett et al., 2001). The CIN probe was suspended from a pylon under a wing. It illuminates a population of cloud particles with laser light at $625 \mathrm{~nm}$ wavelength and measures the near-forward and nearbackward scattered light intensities from cloud particles $2 \mu \mathrm{m}$ and larger. The light scattering coefficients from the CIN probe correspond with the light scattering coefficients calculated from the cloud droplet size distributions measured with the FSSP100 probes (Fig. 3c). The CIN probe provides a measurement that is independent from the FSSP100 probes, thereby avoiding ambiguities that can occur when comparing the CDNC with cloud light extinction.

\section{Observations}

Aerosol number concentrations for particles $>140 \mathrm{~nm}$ $\left(\mathrm{APNC}_{140}\right)$ and $\mathrm{CDNC}$ during profiles through the clouds are shown in Fig. $4 \mathrm{a}$ and b; $140 \mathrm{~nm}$ roughly corresponds to the lower size of particles that will activate to cloud droplets in these types of clouds (e.g. Leaitch et al., 1996; Russell et al., 1999). The mean $\mathrm{APNC}_{140}$ at cloud base during flight 1 was $170 \mathrm{~cm}^{-3} \pm 50 \mathrm{~cm}^{-3}$ and the mean CDNC through the profile was $190 \mathrm{~cm}^{-3} \pm 50 \mathrm{~cm}^{-3}$ for cloud liquid water contents $(\mathrm{LWC})>0.15 \mathrm{~g} \mathrm{~m}^{-3}$; smaller LWC are excluded to remove reductions in the CDNC by evaporation at cloud edges. For flight 2 , the mean $\mathrm{APNC}_{140}$ for cloud base was $390 \mathrm{~cm}^{-3} \pm 100 \mathrm{~cm}^{-3}$ and the mean CDNC through the profile was $560 \mathrm{~cm}^{-3} \pm 110 \mathrm{~cm}^{-3}$. The cloud base aerosol and CDNC sampled during flight 2 are higher than those of flight 1 at a confidence level of $>99 \%$ as in Table 2 . The time series of the observations are shown in Fig. 5.

The LWC profiles were near adiabatic and the steady increase of the LWC from bottom to top indicates lifting from cloud base (Fig. 3); detection of an aerosol-cloud albedo effect is easier for nearly adiabatic clouds (Kim et al., 2008). The cloud light scattering values were higher for the profile of flight 2 (Fig. 3c). Bifurcation of the profile measurements during flight 2 is the result of the aircraft flying momentarily out of the cloud and then back in. The vertically integrated LWC or cloud liquid water path (LWP) is $30 \mathrm{~g} \mathrm{~m}^{-2}$ for the flight 1 profile and $20 \mathrm{~g} \mathrm{~m}^{-2}$ for the flight 2 profile. Despite the lower LWP, the vertically integrated light scattering (optical depth) through the cloud of flight 2 is higher than that of flight 1 (4.2 vs. 3.8) due to the higher CDNC. The cloud 
a. (Flight 1)

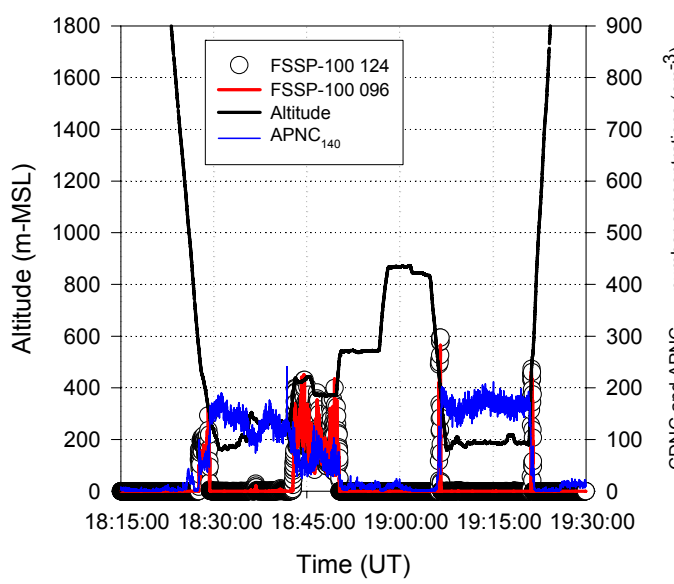

b. (Flight 2)

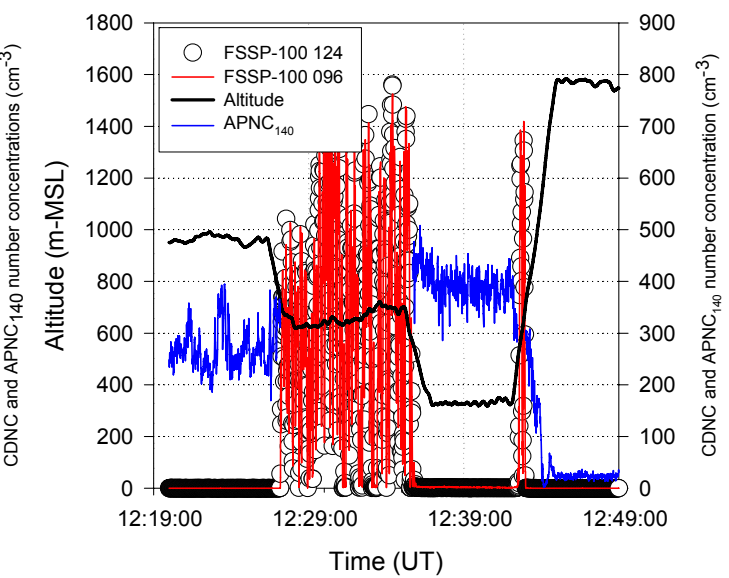

Fig. 5. Time series of altitude, aerosol particle number concentrations $>140 \mathrm{~nm}$ (APNC140) and cloud droplet number concentrations (CDNC) for flights 1 and 2. Observations are for the periods when cloud was profiled and sampling was conducted above, in and below cloud at level intervals. The CDNC are from the two FSSP100 probes (serial numbers 096 and 124) corrected for coincidence and probe dead times (Baumgardner et al., 1985), and the $\mathrm{APNC}_{>140}$ is from the PCASP100X.

Table 3. Aerosol Chemistry at Cloud Base. The mass concentrations of the chemical compounds measured at cloud base with the Q-AMS and the PILS (the PILS values are in parentheses) for the times given in Table 2. The PILS average from flight 2 is shown as a range of two samples that cover segments of the five-minute Q-AMS average. The Q-AMS non-refractory mass concentrations are slightly different than in the profiles of Fig. 7 because they are for level flight only. The $m / z 43,44$ and 57 values are mass concentrations of the corresponding non-refractory carbonaceous ion fragments measured with the Q-AMS; higher $m / z, 44$ indicates organic mass (OM) that is more oxygenated.

\begin{tabular}{lllllllll}
\hline Flt. & $\begin{array}{l}\text { Sulphate } \\
\left(\mu \mathrm{g} / \mathrm{m}^{3}\right)\end{array}$ & $\begin{array}{l}\mathrm{OM} \\
\left(\mu \mathrm{g} / \mathrm{m}^{3}\right)\end{array}$ & $\begin{array}{l}\text { Nitrate } \\
\left(\mu \mathrm{g} / \mathrm{m}^{3}\right)\end{array}$ & $\begin{array}{l}\text { Ammonium } \\
\left(\mu \mathrm{g} / \mathrm{m}^{3}\right)\end{array}$ & $\begin{array}{l}\text { Sodium } \\
\left(\mu \mathrm{g} / \mathrm{m}^{3}\right)\end{array}$ & $\begin{array}{l}\mathrm{m} / \mathrm{z} 43 \\
\left(\mu \mathrm{g} / \mathrm{m}^{3}\right)\end{array}$ & $\begin{array}{l}\mathrm{m} / \mathrm{z} 44 \\
\left(\mu \mathrm{g} / \mathrm{m}^{3}\right)\end{array}$ & $\begin{array}{l}\mathrm{m} / \mathrm{z} 57 \\
\left(\mu \mathrm{g} / \mathrm{m}^{3}\right)\end{array}$ \\
\hline 1 & $2.4(2.1)$ & 0.86 & $0.08(0.0)$ & $0.0(0.18)$ & $0.0(0.02)$ & 0.1 & 0.0 & 0.0 \\
2 & $2.3(1.78-2.65)$ & 2.6 & $0.2(0.25-0.48)$ & $0.0(0.32-0.40)$ & $0.02(0.40-0.72)$ & 0.19 & 0.46 & 0.03 \\
\hline
\end{tabular}

droplet size distributions from one of the FSSP100 probes (096) averaged through each profile are shown in Fig. 6. The mode diameter is about $12 \mu \mathrm{m}$ for the distribution of flight 1 and about $8 \mu \mathrm{m}$ for the flight 2 distribution. Although momentarily flying out of cloud contributes significantly to the lower LWP of flight 2, we note that recent studies have associated increases in aerosol with slight reductions in LWP (Avey et al., 2007; Lebsock et al., 2008).

Profile data of the non-refractory chemical composition of the cloud base fine particle aerosol is shown in Fig. 7. The fine aerosol was dominated by sulphate components on flight 1 and by a mix of organic components (OM: carbonaceous material exclusive of elemental carbon) and sulphate components on flight 2 ; respective fine particle sulphate and OM mass concentrations measured for level flight at cloud base were $2.4 \mu \mathrm{g} \mathrm{m}^{-3}$ and $0.9 \mu \mathrm{g} \mathrm{m}^{-3}$ during flight 1 and $2.3 \mu \mathrm{g} \mathrm{m}^{-3}$ and $2.6 \mu \mathrm{g} \mathrm{m}^{-3}$ during flight 2 (Table 3 ). Collection efficiency aside, the maximum uncertainty for the mass concentrations measured with this Q-AMS is estimated at $\pm 20 \%$ of the mass concentrations (Rupakheti et al., 2005).
For the range $0.06-0.8 \mu \mathrm{m}$, the aerosol particle size distributions at cloud base (Fig. 2) differ principally in number concentration; the flight 2 cloud base number concentration is about twice that of flight 1 above $0.06 \mu \mathrm{m}$. The variations of the mass fractions of OM relative to sulphate plus OM with particle size from $0.1 \mu \mathrm{m}$ to $0.5 \mu \mathrm{m}$ are shown in Fig. $8 \mathrm{a}$. The particle volume concentrations estimated from the sums of sulphate and OM compared with the total volume distributions estimated from the physical size distributions are shown in Fig. 8b; volumes were calculated from the AMS assuming densities of $1.78 \mathrm{~g} \mathrm{~cm}^{-3}$ for sulphate and $1.2 \mathrm{~g} \mathrm{~cm}^{-3}$ for OM. No other chemical species of significant concentration were measured in this size range with the Q-AMS. Mass concentrations of sodium and chloride ions measured with the PILS were associated with coarse particle number concetrations (Fig. 8c). We assume that the discrepancies in the volume concentrations above $0.5 \mu \mathrm{m}$ (Fig. $8 \mathrm{~b}$ ) are explained by sea salt components. Table 4 summarizes the physical properties of the cloud base aerosols observed during the two flights. 


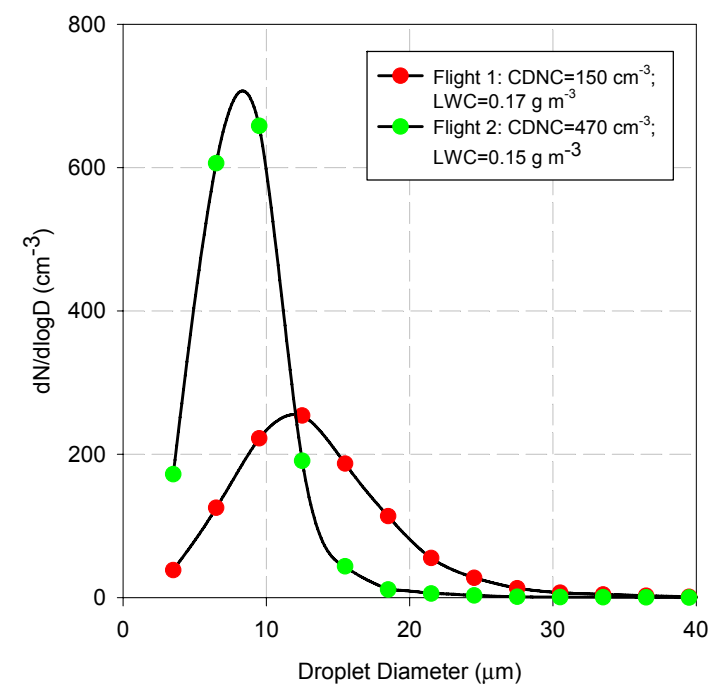

Fig. 6. Droplet size distributions averaged through the profile from each flight from one of the FSSP100 probes.

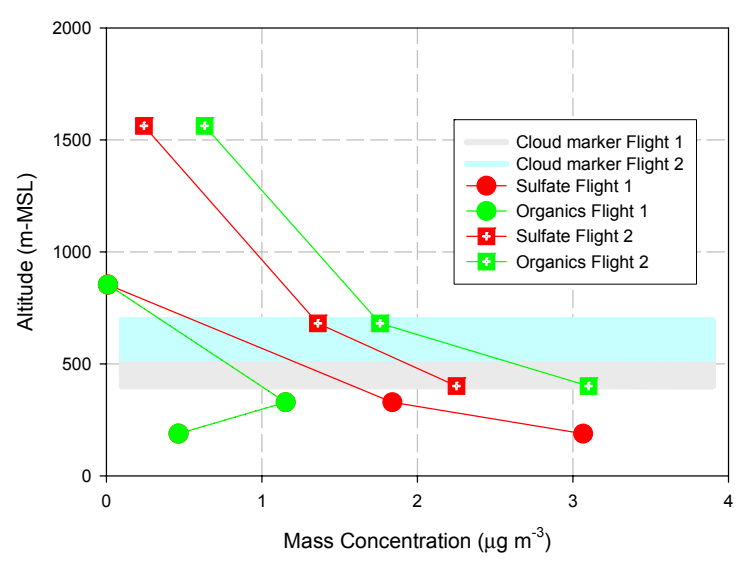

Fig. 7. Vertical profiles of sulphate and total organic mass concentrations from the Q-AMS. Each data point is a $5 \mathrm{~min}$ average. The shading indicates the approximate region of cloud.

The time series of vertical gusts or updraft speeds are shown in Fig. 9. We sample the updrafts across the maximum available level-flight path in cloud. For a sufficient path length in this type of cloud, the mean of the gusts is zero by definition. The variations in updraft speeds represent the potential influence on the CDNC. We use one standard deviation of the vertical gust measurements during level flight, as discussed by Peng et al. (2005), to define the variation. One standard deviation is $14 \mathrm{~cm} \mathrm{~s}^{-1}$ for flight 1 and $50 \mathrm{~cm} \mathrm{~s}^{-1}$ for flight 2 . The maximum gusts were approximately $20 \mathrm{~cm} \mathrm{~s}^{-1}$ for flight 1 and $100 \mathrm{~cm} \mathrm{~s}^{-1}$ for flight 2 .
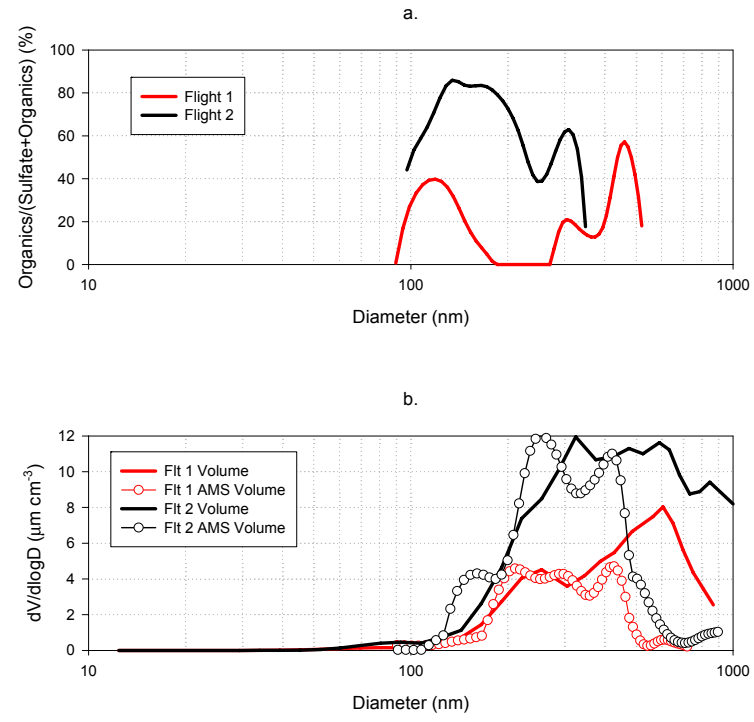

c.

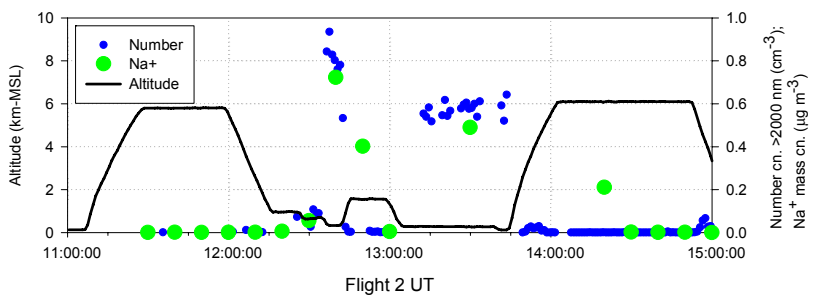

Fig. 8. (a) Below-cloud ratios of OM (organics) to sulphate plus OM from the Quadrapole Aerosol Mass Spectrometer (Q-AMS) as a function of size; (b) below-cloud volume distributions from the Q-AMS and the physical measurements; (c) time series of sodium mass concentrations (from the PILS) and the number concentrations of particles $>2000 \mathrm{~nm}$ aerodynamic diameter for flight 2 . The relative increase in particles $>2000 \mathrm{~nm}$ at lower altitudes, the association of sodium with increased concentrations of these larger particles and the higher winds speeds of flight 2 suggest the presence of sea salt particles.

\section{Modelling}

The aerosol-cloud adiabatic parcel model includes representation of weakly soluble compounds (Shantz et al., 2003) as well as the effects of different surface tensions (Lohmann et al., 2004). The cloud base aerosol size distributions are described by multiple modes each represented as a log-normal function (Fig. 2b). The chemical representations of each mode are based on the AMS and PILS data for particles $>0.1 \mu \mathrm{m}$. Smaller particles are assumed to be either $100 \%$ $\mathrm{H}_{2} \mathrm{SO}_{4}$ or $70 \%$ organic and $30 \%$ sulphate by mass, as indicated. Table 5 gives the physical and chemical representations for each mode used in the simulations; other initial conditions used in the simulations are given at the bottom of Table 5. Except as discussed, all chemical components within each mode are assumed to be internally mixed. The 
Table 4. Summary of Aerosol Physical Size Distribution Measurements at Cloud Base.

\begin{tabular}{lllllll}
\hline & Flight 1 & $\begin{array}{l}\text { Number } \\
\text { Cn. }\end{array}$ & $\begin{array}{l}\text { Mass estimate } \\
\left(\rho=1.7 \mathrm{~g} \mathrm{~cm}^{-3}\right)\end{array}$ & Flight 2 & $\begin{array}{l}\text { Number } \\
\mathrm{Cn} .\end{array}$ & $\begin{array}{l}\text { Mass estimate } \\
\left(\rho=1.5 \mathrm{~g} \mathrm{~cm}^{-3}\right)\end{array}$ \\
\hline Mode & $\begin{array}{l}\text { Size range } \\
\text { GD }(\mathrm{nm})\end{array}$ & $\left(\mathrm{cm}^{-3}\right)$ & $\left(\mu \mathrm{g} \mathrm{m}^{-3}\right)$ & $\begin{array}{l}\text { Size range } \\
\text { GD }(\mathrm{nm})\end{array}$ & $\left(\mathrm{cm}^{-3}\right)$ & $\left(\mu \mathrm{g} \mathrm{m}^{-3}\right)$ \\
\hline 1 & $10-115$ & 408 & 0.09 & $10-115$ & 537 & 0.17 \\
2 & $115-500$ & 246 & 2.6 & $115-500$ & 498 & 6.4 \\
3 & $500-900$ & 13.9 & 2.4 & $500-900$ & 20 & 3.8 \\
4 & $900-18000$ & 1.0 & 5.4 & $900-18000$ & 4.2 & 57.5 \\
All & & 668 & 10.5 & & 1059 & 67.9 \\
\hline
\end{tabular}

Table 5. Model Initial Conditions.

\begin{tabular}{lllll}
\hline & Geo. Mean Dia. & Geo. Std. Dev. & Num. Cn. & Composition \\
\hline Flight 1 & $(\mathrm{~nm})$ & & $\left(\mathrm{cm}^{-3}\right)$ & \\
\hline Mode 1 & 56 & 1.48 & 395 & $\mathrm{H}_{2} \mathrm{SO}_{4}$ \\
Mode 2 & 200 & 1.40 & 250 & $25 \%$ Org and $75 \% \mathrm{H}_{2} \mathrm{SO}_{4}$ \\
Mode 3 & 560 & 1.22 & 14 & $25 \%$ Org and $75 \% \mathrm{H}_{2} \mathrm{SO}_{4}$ \\
Mode 4 & 1200 & 1.45 & 1.8 & $\mathrm{NaCl}$ \\
Total & & & 661 & \\
\hline
\end{tabular}

\begin{tabular}{lllll}
\hline Flight 2 & & & \\
\hline Mode 1 & 30 & 1.40 & 79 & $\mathrm{H}_{2} \mathrm{SO}_{4}$ \\
Mode 2 & 74 & 1.32 & 461 & $\mathrm{H}_{2} \mathrm{SO}_{4}$ or $70 \%$ Org and $30 \% \mathrm{H}_{2} \mathrm{SO}_{4}$ \\
Mode 3 & 200 & 1.47 & 503 & $70 \%$ Org and $30 \% \mathrm{H}_{2} \mathrm{SO}_{4}$ \\
Mode 4 & 540 & 1.30 & 17.7 & $25 \%$ Org and $75 \% \mathrm{H}_{2} \mathrm{SO}_{4}$ \\
Mode 5 & 3000 & 1.60 & 1.7 & $\mathrm{NaCl}$ \\
Total & & & 1062 & \\
\hline
\end{tabular}

- Pressure $960 \mathrm{mb}$, both flights

- Temperature, $17.2^{\circ} \mathrm{C}$ (Flt 2), $12.5^{\circ} \mathrm{C}$ (Flt 1)

- Starting RH, $98 \%$

- Accommodation coefficient for water, 1.0; sensitivity to 0.06 .

- Organic osmotic coefficient, 1.0

- Organic dissociation factor, 1.0

- Organic MW, $150 \mathrm{~g} \mathrm{~mole}^{-1}$

- Organic surface tension adipic acid; sensitivity to pure water tested.

simulated CDNC are defined as droplets $>2 \mu \mathrm{m}$ diameter that are still growing after the maximum supersaturation is reached, in accordance with the lower size of the FSSP100 and the measured droplet distributions (Fig. 6).

The model uses a cloud updraft speed to define the rate of cooling of the air parcel that eventually leads to a water supersaturation and nucleation of cloud droplets; higher updraft speeds increase the cloud base supersaturation and the resulting droplet growth rates. The method of assessing the appropriate updraft speed to use with an adiabatic parcel model is not well established. In the case of stratiform cloud, as in the present study, it is difficult if not impossible to identify an updraft core. We use the results of the Peng et al. (2005) analysis that indicated a value of one standard deviation of the measured gust velocities provided the best closure of the aerosol and cloud measurements. The physical basis for this is that the smaller positive updrafts sampled when flying level through a stratiform cloud are the result of changes in the stronger vertical motions within cloud, and they are not the updrafts that penetrate from below cloud base up into the cloud. In other words, there is some distribution of higher updrafts that specify CDNC in the cloud. Based on this reasoning, we expect the updraft speeds higher than one standard deviation are also a factor in determining 

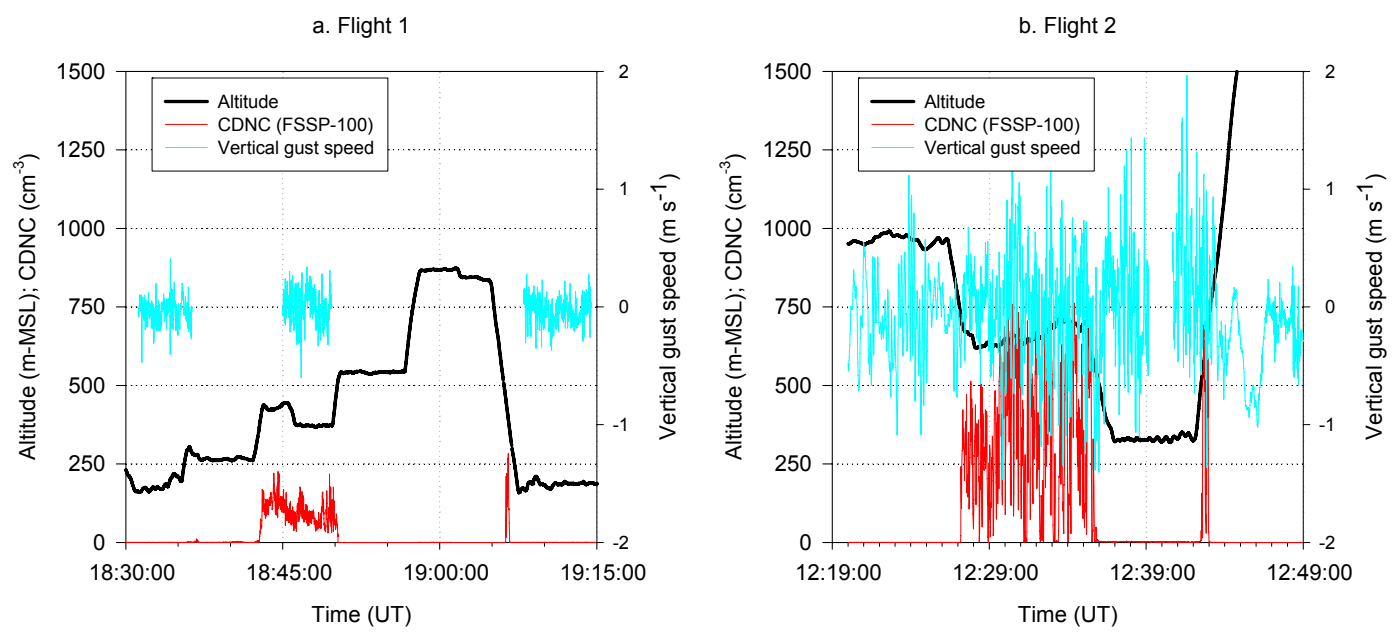

Fig. 9. Vertical gust speeds while flying level during flights 1 and 2 (cyan curves). The presence of cloud is indicated by the CDNC (red curves) and altitude is also shown (black curves). The values of one standard deviation of the measured gust speeds are $14 \mathrm{~cm} \mathrm{~s}^{-1}$ for flight 1 and $50 \mathrm{~cm} \mathrm{~s}^{-1}$ for flight 2; the means of the gust speeds for each flight segment are zero. The ranges of the gusts are approximately $20 \mathrm{~cm}$ $\mathrm{s}^{-1}$ for flight 1 and $100 \mathrm{~cm} \mathrm{~s}^{-1}$ for flight 2 .

the CDNC. As discussed above, we use updraft speeds of $14 \mathrm{~cm} \mathrm{~s}^{-1}$ for flight 1 and $50 \mathrm{~cm} \mathrm{~s}^{-1}$ for flight 2 as principal model inputs. We also conduct simulations with the maximum gusts: $20 \mathrm{~cm} \mathrm{~s}^{-1}$ for flight 1 and $100 \mathrm{~cm} \mathrm{~s}^{-1}$ for flight 2. As discussed below, we also apply the updraft speeds of flight 2 to the aerosol of flight 1.

The sensitivity of the simulated CDNC to the assumption of the composition of the smallest particles that can contribute to the CDNC in this case (mode 2 in Table 5) was considered in the case of flight 2 by changing the composition from $\mathrm{H}_{2} \mathrm{SO}_{4}$ to $70 \% \mathrm{OM}$ and $30 \% \mathrm{H}_{2} \mathrm{SO}_{4}$ assuming a solubility of $5 \mathrm{~g}^{-1}$ for the OM. The sensitivity to the assumption of an internal mix of the organics and the sulphate was tested by assuming that the OM and the sulphate in modes 2 and 3 of flight 2 were externally mixed. These results are shown under "External mixture" in Table 6. The surface tension used in these calculations is based on that of adipic acid (Ervens et al., 2004). The impact of this surface tension is considered by simulating the flight 2 internally mixed cases for a surface tension of water plus ammonium sulphate for the OM solubilities of 5 and $200 \mathrm{gl}^{-1}$ and for updrafts of 50 and $100 \mathrm{~cm} \mathrm{~s}^{-1}$. These cases were selected because they are the conditions closest to the observations and should offer the greatest sensitivity to the surface tension due to the higher organic concentrations in solution.

We use a value of unity for $\alpha_{\mathrm{c}}$ in the simulations, assuming that the droplets by the time they reach cloud base are sufficiently dilute that $\alpha_{\mathrm{c}}=1$ is appropriate. We also test the effect of defining $\alpha_{\mathrm{c}}$ as 0.06 as used by Conant et al. (2004) and by Fountoukis et al. (2007).

The cloud albedo $\left(A_{c}\right)$ is calculated using

$A_{\mathrm{c}}=\tau /(7.7+\tau)$ where $\tau$ is the optical depth calculated from the integration of the extinction measurements through the cloud profile (e.g. Menon et al., 2003). The planetary albedo $\left(A_{\mathrm{p}}\right)$ using

$A_{\mathrm{p}}=A_{\mathrm{c}}+\left[\left(1-A_{\mathrm{c}}\right)^{2} A_{\mathrm{s}}\right] /\left(1-A_{\mathrm{c}} A_{\mathrm{s}}\right)$

where in this case $A_{\mathrm{s}}$ is the underlying reflectance from the ocean surface and assumed to be 0.1 . The local radiative forcing is simply estimated assuming an increase of $-2 \mathrm{~W} \mathrm{~m}^{-2}$ for a planetary albedo increase of $0.5 \%$ (Ramanathan, 1988).

\section{Results and discussion}

The CDNC simulated for flight 1 assuming internally mixed sulphate and OM $\left(225 \mathrm{~cm}^{-3}\right.$; Table $\left.6,14 \mathrm{~cm} \mathrm{~s}^{-1}\right)$ are within the range of the observed values $\left(140-240 \mathrm{~cm}^{-3}\right)$ and within $18 \%$ of the observed mean CDNC. There is little or no change in the CDNC with change in the OM solubility due to the relatively large sulphate fraction that controls water uptake. For flight 2, the CDNC was simulated for the three possible unique states of the cloud base aerosol. First, for the assumption that the carbonaceous components of flight 2 were particles externally mixed relative to the sulphate components and either hydrophobic or weakly hygroscopic (Fig. 10a) the simulated CDNC $\left(370 \mathrm{~cm}^{-3}\right.$; Table 6$)$ is outside of the range of the observed CDNC $\left(450-770 \mathrm{~cm}^{-3}\right)$ and $34 \%$ lower than the mean. Second, for the assumption that the carbonaceous particles were externally mixed and highly hygroscopic (Fig. 10b) the resulting CDNC $\left(560 \mathrm{~cm}^{-3}\right.$; Table 6) is equivalent to the mean of the observed CDNC. Third, for the assumption that carbonaceous particles served primarily as substrates for sulphate condensation (internal 
Table 6. Simulated Cloud Droplet Number Concentrations $\left(\mathrm{CDNC}, \mathrm{cm}^{-3}\right)$. Values are for smaller particles $(<100 \mathrm{~nm})$ represented as $\mathrm{H}_{2} \mathrm{SO}_{4}$; values in parentheses are for smaller particles represented as $70 \%$ organic and $30 \% \mathrm{H}_{2} \mathrm{SO}_{4}$.

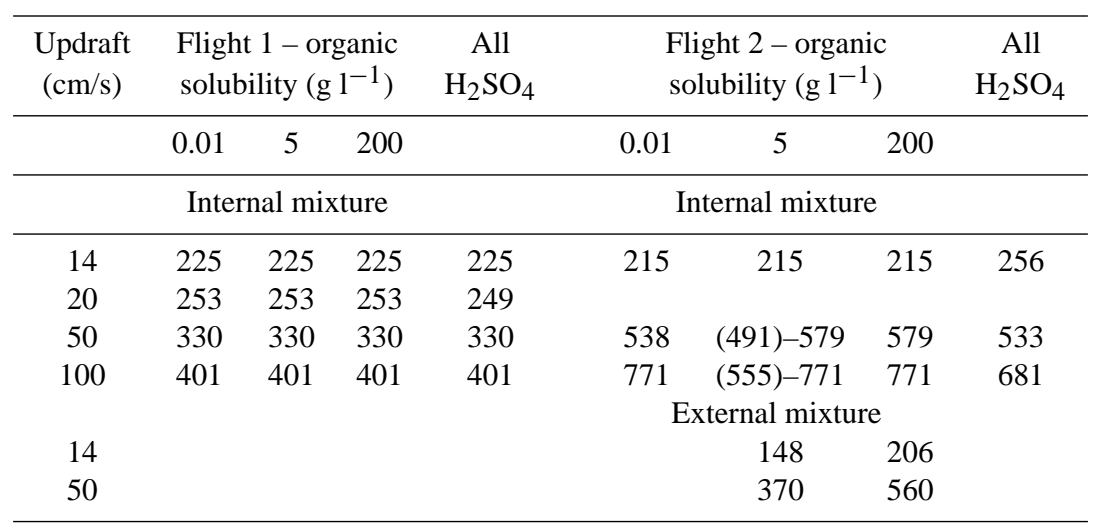

mixture, Fig. 10c) and defined the $\mathrm{CCN}$ number concentration the simulated CDNC (491-579 $\mathrm{cm}^{-3}$; Table 6) are within the range of the observed $\mathrm{CDNC}$ and the mean $\left(535 \mathrm{~cm}^{-3}\right)$ is within $7 \%$ of the observed mean. Reducing the surface tension in these models produced no significant change in the CDNC, and reducing the mass accommodation coefficient to 0.06 (e.g. Fountoukis et al., 2007) increased the CDNC by $12 \%$. The only aerosol model of flight 2 that does not represent the increase in the CDNC of flight 2 relative to flight 1 is that which assumes no effect of the carbonaceous particles on the CDNC (Fig. 10a). Thus, we find that the carbonaceous components of the below-cloud aerosol contributed to the increase in the CDNC.

The updraft speed of flight 2 is applied to the flight 1 aerosol in order to assess the degree to which the higher updrafts of flight 2 were responsible for the higher CDNC. The resulting increase in the CDNC $\left(330 \mathrm{~cm}^{-3}\right.$ from $225 \mathrm{~cm}^{-3}$; Table 6) is about $30 \%$ of the difference between flights 1 and $2\left(560 \mathrm{~cm}^{-3}\right.$ from $\left.225 \mathrm{~cm}^{-3}\right)$, leaving $70 \%$ of the increase attributable to the change in the aerosol. For $70 \%$ of the difference in the optical depths (4.2-3.8), we estimate that the increase in aerosol due to the carbonaceous components produced a local increase in cloud albedo of $5.5 \%$, which equates to a local radiative forcing of approximately $-12 \mathrm{~W} \mathrm{~m}^{-2}$ for an ocean surface reflectance of $10 \%$. Any additional absorption effects from the increase in carbonaceous components of flight 2 are not considered in this estimate, while the absolute value of the forcing is underestimated due to the reduced vertically integrated cloud liquid water of flight 2 .

The above attribution is predicated on the higher updraft speed during flight 2 as the application of the weaker updraft of flight 1 to the aerosol of flight 2 simulates a CDNC that is slightly lower than that of flight 1 . A lower updraft slows the rate of condensation, and only $\mathrm{CCN}$ with larger critical diameters will activate or reach cloud droplet size. In

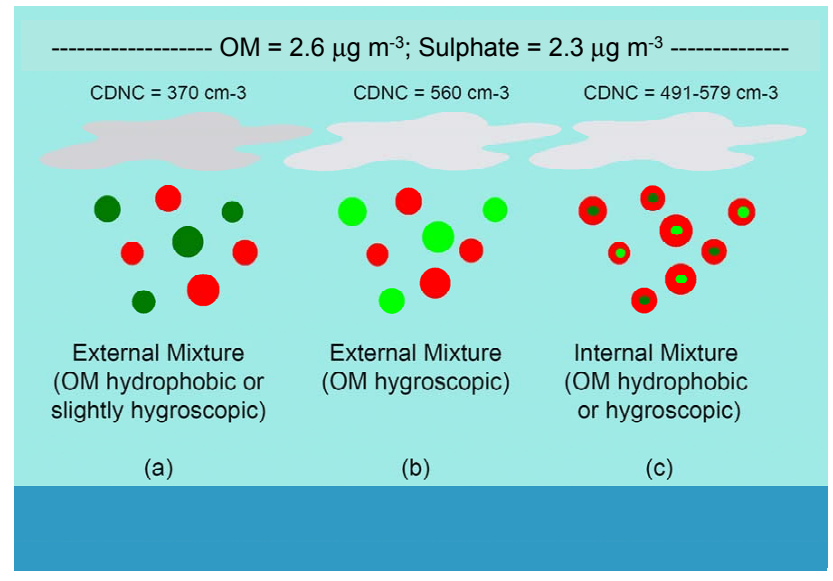

Fig. 10. Scenarios of aerosol component mixing and modelled cloud droplet number concentrations for flight 2. (a) The carbonaceous (green) and sulphate (red) components are externally mixed with no water uptake by the carbonaceous particles; (b) externally mixed and the carbonaceous particles strongly influence the water uptake; (c) internally mixed carbonaceous and sulphate components with no effect of the carbonaceous components on water uptake.

that situation, the chemistry has a substantial bearing on the lower activation diameter; $\mathrm{CCN}$ observations that point to the importance of the size distribution do not consider supersaturations $<0.1 \%$ that are relevant to flight 1 . At higher updraft speeds, the cloud base supersaturation is higher (up to $0.2 \%$ as modelled for flight 2; Fig. 11), the critical diameter of activation is smaller and the number distribution becomes a stronger influence for the CDNC; however the chemistry of the larger $\mathrm{CCN}$ still is important due to its control of the cloud base supersaturation via its effect on the water uptake rate. This point is illustrated here by the decrease in the CDNC for the assumption that the aerosol of flight 2 is all sulphate and the updraft speed of $100 \mathrm{~cm} \mathrm{~s}^{-1}$ or greater. It is 


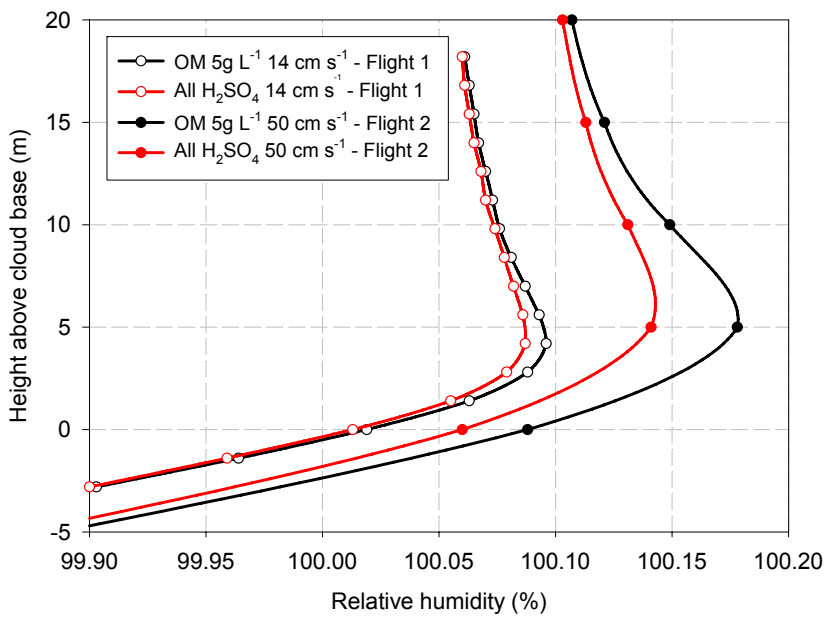

Fig. 11. Examples of the simulated profiles of relative humidity just below and above cloud base. The air is supersaturated with respect to water where the relative humidity exceeds $100 \%$. Cases of weak solubility of the $\mathrm{OM}\left(5 \mathrm{gl}^{-1}\right)$ and pure $\mathrm{H}_{2} \mathrm{SO}_{4}$ are shown for both flights 1 and 2. The water supersaturation decreases when the aerosol is all sulphuric acid due to the more rapid rate of water uptake by this chemical component.

also consistent with the suggestion that the assumption of organic compounds as hygroscopic affects the sensitivity of the CDNC to the vertical velocity (Rissman et al., 2004; Lance et al., 2004).

Since the flight 2 observations were made at least one day or more downwind of significant carbonaceous aerosol sources (Fig. 1b) the sulphate and carbonaceous components were internally mixed to some degree (e.g., Covert and Heintzenberg, 1984; Heald et al., 2005). Also, previous observations of the residuals of cloud droplets from marine clouds have found that both components co-exist in cloud water (e.g., Straub et al., 2007; Targino et al., 2007; Hawkins et al., 2008). This is the situation represented in Fig. 10c, in which case the ability of the carbonaceous components to affect the water uptake rate of the flight 2 aerosol has a relatively small effect on the simulated CDNC (Table 6) due to the influence of the sulphate. However, if we assume that the particles are composed completely of sulphate a slight reduction in the CDNC results because the large increase in droplet growth rates reduces the cloud base supersaturation (Figure 10); despite the slightly lower value, the CDNC resulting from the all sulphate scenario falls within the range of the observed CDNC.

The effects of carbonaceous components on the CDNC are inherent in the sulphate-CDNC empirical parameterization (Penner et al., 2001), but they can not be separated from those of sulphate. Menon et al. (2002) developed an empirical relationship for CDNC in an attempt to explicitly identify changes in the CDNC due to changes in sulphate, organic, and sea salt mass concentrations. Application of that for- mulation to the present observations produces only a $15 \%$ increase in the CDNC from flight 1 to flight 2 compared with the $70 \%$ increase based on the present observations and analysis. Pringle et al. (2009) finds no reason to suggest mechanistic models are currently better than empirical models, other than the potential for the mechanistic model to better represent regional effects. However, as we begin to consider the effects of changes in emissions (e.g. Kloster et al., 2008), our result emphasises the point that accurate distinction between the carbonaceous and sulphur components is essential for assessing changes in the cloud albedo effect, and continued development of mechanistic approaches is the only way to achieve the needed confidence in our ability to predict effects of emissions changes.

\section{Summary and conclusions}

We compare measurements made above, in and below stratocumulus during flights on two sequential days over the Atlantic Ocean to consider the effect of carbonaceous aerosol particles on the reflectivity of sunlight by water clouds. On the first day, the below-cloud fine particle aerosol was mostly of marine character and the cloud base fine particle sulphate and organic carbon mass concentrations measured with a QAMS were $2.4 \mu \mathrm{g} \mathrm{m}^{-3}$ and $0.9 \mu \mathrm{g} \mathrm{m}^{-3}$ respectively. On the second day, the below-cloud aerosol was also continentally influenced and the sulphate and organic carbon mass concentrations from the Q-AMS were $2.3 \mu \mathrm{g} \mathrm{m}^{-3}$ and $2.6 \mu \mathrm{g} \mathrm{m}^{-3}$ respectively. Correspondingly, the number concentrations of aerosol particles below cloud were approximately a factor of two higher on the second day, while the shapes of the below-cloud size distributions over $0.06-0.8 \mu \mathrm{m}$ diameter were similar on both days. The CDNC on the second day were approximately three times higher than the CDNC measured on the first day. In addition, the measured cloud light scattering was higher on the second day despite a slightly lower liquid water content. The vertically integrated cloud light extinctions indicate an increase in the cloud albedo from the first day to the second day of approximately $8 \%$. Using an aerosol-adiabatic cloud parcel model to separate the influence of the differences in the cloud gust velocities, we estimate that fractionally 0.7 of the $8 \%$ increase in cloud albedo on the second day was due to the higher concentrations of below-cloud aerosol that principally resulted from the increase in the carbonaceous components of that aerosol. Assuming no additional absorption by this aerosol, the estimated local albedo increase due the carbonaceous components in the aerosol translates to a daytime radiative cooling of $\sim 12 \mathrm{~W} \mathrm{~m}^{-2}$.

Although we only contrast two cases, the result suggests that the contribution to radiative forcing via the cloud albedo effect from carbonaceous components can be not only substantial but significantly higher than the contribution from 
sulphate, in agreement with some global models using mechanistic approaches to represent the aerosol and CDNC.

Acknowledgements. We thank C-SOLAS, Rodney Weber, Mohammed Wasey, Mark Couture, Rachel Chang, Rachel Schwartz, Ryan Leaitch and the Institute for Aerospace Research. Funding was provided by the Natural Sciences and Engineering Research Council of Canada, the Canadian Foundation for Climate and Atmospheric Science, and Environment Canada. The authors gratefully acknowledge the NOAA Air Resources Laboratory (ARL) for the provision of the HYSPLIT transport and dispersion model and/or READY website (http://www.arl.noaa.gov/ready.php) used in this publication.

Reviewed by: M. Petters

\section{References}

Allan, J. D., Jimenez, J. L., Coe, H., Bower, K. N., Williams, P. I., Canagaratna, M. R., Jayne, J. T., and Worsnop, D. R.: Quantitative sampling using an Aerodyne aerosol mass spectrometer 1. Techniques of data interpretation and error analysis, J. Geophys. Res., 108, 4090-4100, 2003.

Avey, L., Garrett, T. J., and Stohl, A.: Evaluation of the aerosol indirect effect using satellite, tracer transport model, and aircraft data from the International Consortium for Atmospheric Research on Transport and Transformation, J. Geophys. Res., 112, D10S33, doi:10.1029/2006JD007581, 2007.

Bahadur, R., Habib, G., and Russell, L. M.: Climatology of PM2.5 Organic Carbon Concentrations from a Review of Ground-Based Atmospheric Measurements by Evolved Gas Analysis, Atmos. Environ. 43, 1591-1602, 2009.

Baumgardner, D., Strapp, J. W., and Dye, J. E.: Evolution of the forward scattering spectrometer probe, part II: Corrections for coincidence and dead time errors, J. Atmos. Oceanic Technol., 2, 626-632, 1985.

Buset, K. C., Evans, G. J., Leaitch, W. R., Brook, J. R., and ToomSauntry, D.: Use of Advanced Receptor Modeling for Analysis of an Intensive 5-Week Aerosol Sampling Campaign, Atmos. Environ., 40, 482-499, 2006.

Chang, R. Y.-W., Liu, P. S. K, Leaitch, W. R., and Abbatt, J. P. D.: Comparison between measured and predicted $\mathrm{CCN}$ concentrations at Egbert, Ontario: Focus on the organic aerosol fraction at a semi-rural site, Atmos. Environ., 41, 8172-8182, 2007.

Chuang, C. C., Penner, J. E., Prospero, J. M., Grant, K. E., Rau, G. H., and Kawamoto, K.: Cloud susceptibility and the first aerosol indirect forcing: Sensitivity to black carbon and aerosol concentrations, J. Geophys. Res., 107, doi:10.1029/2000JD000215, 2002.

Cober, S. G., Isaac, G. A., Korolev, A. V., and Strapp, W.: Assessing Cloud-Phase Conditions, J. Appl. Meteorol., 40, 1967-1983, 2001.

Conant, W. C., VanReken, T. M., Rissman, T. A., Varutbangkul, V., Jonsson, H. H., Nenes, A, Jimenez, J. L., Delia, A. E., Bahreini, R., Roberts, G. C., Flagan, R. C., Seinfeld, J. H., Aerosol cloud drop concentration closure in warm cumulus, J. Geophys. Res., 109, D13204, doi:10.1029/2003JD004324, 2004.
Covert, D. S. and Heintzenberg, J.: Measurement of the Degree of Internal External Mixing of Hygroscopic Compounds and Soot in Atmospheric Aerosols, Sci. Total Environ., 36, 347-352, 1984.

Davidovits, P., Worsnop, D. R., Jayne, J. T., Kolb, C. E., Winkler, P., Vrtala, A., Wagner, P. E., Kulmala, M., Lehtinen, K. E. J., Vesala, T., and Mozurkewich, M.: Mass accommodation coefficient of water vapor on liquid water, Geophys. Res. Lett., 31, L22111, doi:10.1029/2004GL020835, 2004.

Draxler, R. R. and Rolph, G. D.: HYSPLIT (HYbrid Single-Particle Lagrangian Integrated Trajectory) Model access via NOAA ARL READY Website (http://www.arl.noaa.gov/ HYSPLIT.php). NOAA Air Resources Laboratory, Silver Spring, MD, 2003.

Drummond, A. M. and MacPherson, J. I.: Aircraft flow effects on cloud drop images and concentration measured by the NAE Twin Otter, J. Atmos. Oceanic Technol., 2, 633-643, 1985.

Dusek, U., Frank, G. P., Hildebrandt, L., Curtius, J., Schneider, J., Walter, S., Chand, D., Drewnick, F., Hings, S., Jung, D., Borrmann, S., Andreae, M. O.: Size Matters More Than Chemistry for Cloud-Nucleating Ability of Aerosol Particles, Science, 312, 1375-1378, 2006.

Ervens, B., Feingold, G., Clegg, S. L., and Kreidenweis, S. M.: A modeling study of aqueous production of dicarboxylic acids: 2 . Implications for cloud microphysics, J. Geophys. Res., 109, D15, doi:10.1029/2004JD004575, 2004.

Feingold, G. and Chuang, P. Y.: Analysis of the influence of filmforming compounds on droplet growth: implications for cloud microphysical processes and climate, J. Atmos. Sci., 59, 20062018, 2002.

Forster, P., Ramaswamy, V., Artaxo, P., Berntsen, T., Betts, R., Fahey, D., Haywood, J., Lean, J., Lowe, D., Myhre, G., Nganga, J., Prinn, R., Raga, G., Schulz, M., and Van Dorland, R.: Radiative Forcing of Climate Change, in: Climate Change 2007: the Physical Science Basis, Contribution of Working Group I to the Fourth Assessment Report of the Intergovernmental Panel on Climate Change, edited by: Solomon, S., Qin, D., Manning, M., Chen, Z., Marquis, M., Averyt, K. B., Tignor, M., and Miller, H., Cambridge Univ. Press, New York, 129-234, 2007.

Fountoukis, C., Nenes, A., Meskhidze, N., Bahreini, R., Conant, W. C., Jonsson, H., Murphy, S., Sorooshian, A., Varutbangkul, V., Brechtel, F., Flagan, R. C., and Seinfeld, J. H.: Aerosol-cloud drop concentration closure for clouds sampled during the International Consortium for Atmospheric Research on Transport and Transformation 2004 campaign, J. Geophys. Res., 112, D10S30, doi:10.1029/2006JD007272, 2007.

Garrett, T. J., Hobbs, P. V., and Gerber, H.: Shortwave, singlescattering properties of arctic ice clouds, J. Geophys. Res., 106, 15155-15172, 2001.

Gerber, H., Takano, Y., Garrett, T. J., and Hobbs, P. V.: Nephelometer measurements of the asymmetry parameter, volume extinction coefficients and backscatter ratio in Arctic clouds, J. Atmos. Sci., 57, 3021-3034, 2000.

Ghan, S., Easter, R. G., Chapman, E., Abdul-Razzak, H., Zhang, Y., Leung, L. R., Laulainen, N. S., Saylorand, R. D., Zaveri, R. A.: A physically based estimate of radiative forcing by anthropogenic sulfate aerosol, J. Geophys. Res., 106, 5279-5293, 2001. 
Gunthe, S. S., King, S. M., Rose, D., Chen, Q., Roldin, P., Farmer, D. K., Jimenez, J. L., Artaxo, P., Andreae, M. O., Martin, S. T., and Pöschl, U.: Cloud condensation nuclei in pristine tropical rainforest air of Amazonia: size-resolved measurements and modeling of atmospheric aerosol composition and CCN activity, Atmos. Chem. Phys., 9, 7551-7575, doi:10.5194/acp-9-75512009, 2009.

Hawkins, L. N., Russell, L. M., Twohy, C. H., and Anderson, J. R.: Uniform particle-droplet partitioning of 18 organic and elemental components measured in and below DYCOMSII stratocumulus clouds, J. Geophys. Res., 113, D14201, doi:10.1029/2007JD009150, 2008.

Heald, C. L., Jacob, D. J., Park, R. J., Russell, L. M., Huebert, B. J., Seinfeld, J. H., Liao, H., and Weber, R. J.: A large organic aerosol source in the free troposphere missing from current models, Geophys. Res. Lett., 32, L18809, doi:10.1029/2005GL023831, 2005.

Jayne, J. T., Leard, D. C., Ahang, X., Davidovits, P., Smith, K. A., Kolb, C. E., and Worsnop, D. R.: Development of an Aerosol Mass Spectrometer for Size and Composition Analysis of Submicron Particles, Aerosol Sci. Technol., 33, 49-70, 2000.

Jimenez, J. L., Jayne, J. T., Shi, Q., Kolb, C. E., Worsnop, D. R., Yourshaw, I., Seinfeld, J. H., Flagan, R. C., Zhang, X., Smith, K. A., Morris, J. W., and Davidovits, P.: Ambient aerosol sampling using the Aerodyne Aerosol Mass Spectrometer, J. Geophys. Res., 108, 8245-8258, 2003.

Johnson, G. R., Ristovski, Z. D., D'Anna, B., and Morawska, L.: Hygroscopic behavior of partially volatilized coastal marine aerosols using the volatilization and humidification tandem differential mobility analyzer technique, J. Geophys. Res.-Atmos., 110, D20203, doi:10.1029/2004JD005657, 2005.

Kim, B.-G., Miller, M. A., Schwartz, S. E., Liu, Y., and Min, Q.: The role of adiabaticity in the aerosol first indirect effect, J. Geophys. Res., 113, D05210, doi:10.1029/2007JD008961, 2008.

King, S. M., Rosenoern, T., Shilling, J. E., Chen, Q., and Martin, S. T.: Cloud condensation nucleus activity of secondary organic aerosol particles mixed with sulfate, Geophys. Res. Lett., 34, L24806, doi:10.1029/2007GL030390, 2007.

Kloster, S., Dentener, F., Feichter, J., Raes, F., van Aardenne, J., Roeckner, E., Lohmann, U., Stier, P., and Swart, R.: Influence of future air pollution mitigation strategies on total aerosol radiative forcing, Atmos. Chem. Phys., 8, 6405-6437, doi:10.5194/acp-86405-2008, 2008.

Laaksonen, A., Vesala, T., Kulmala, M., Winkler, P. M., and Wagner, P. E.: Commentary on cloud modelling and the mass accommodation coefficient of water, Atmos. Chem. Phys., 5, 461-464, doi:10.5194/acp-5-461-2005, 2005.

Lance, S., Nenes, A., and Rissman, T.: Chemical and dynamical effects on cloud droplet number: implications for estimates of the aerosol indirect effect., J. Geoph. Res., 109, D22208, doi:10.1029/2004JD004596, 2004.

Langley, L., Leaitch, W. R., Lohmann, U., Shantz, N. C., and Worsnop, D. R.: Contributions from DMS and ship emissions to CCN observed over the summertime North Pacific, Atmos. Chem. Phys., 10, 1287-1314, doi:10.5194/acp-10-1287-2010, 2010

Leaitch, W. R., Strapp, J. W., Isaac, G. A., and Hudson, J. G.: Cloud droplet nucleation and cloud scavenging of aerosol sulphate in polluted atmospheres, Tellus, 38B, 328-344, 1986.
Leaitch, W. R., Banic, C. M., Isaac, G. A., Couture, M. D., Liu, P. S. K., Gultepe, I., Li, S.-M., Kleinman, L. I., Daum, P. H., and MacPherson, J. I: Physical and chemical observations in marine stratus during 1993 NARE: factors controlling cloud droplet number concentrations, J. Geophys. Res., 101, 29123-29135, 1996.

Lebsock, M. D., Stephens, G. L., and Kummerow, C.: Multisensor satellite observations of aerosol effects on warm clouds, J. Geophys. Res., 113, D15, doi:10.1029/2008JD009876, 2008.

Liu, P. S. K., Deng, R., Smith, K. A., Williams, L. R., Jayne, J. T., Canagaratna, M. R., Moore, K., Onasch, T. B., Worsnop, D. R., and Deshler, T.: Transmission Efficiency of an Aerodynamic Focusing Lens System: comparison of Model Calculations and Laboratory Measurements for the Aerodyne Aerosol Mass Spectrometer, Aerosol Sci. Tech., 41, 721-733, 2007.

Lohmann, U., Feichter, J., Penner, J., and Leaitch, R.: Indirect effect of sulfate and carbonaceous aerosols-A mechanistic treatment, J. Geophys. Res., 105, 12193-12206, 2000.

Lohmann, U., Leaitch, R., Shantz, N., Broekhuizen, K., and Abbatt, J.: How efficient is cloud droplet formation of organic aerosols? Geophys. Res. Lett., 31, L05108, doi:10.1029/2003GL018999, 2004.

Lohmann, U., Stier, P., Hoose, C., Ferrachat, S., Kloster, S., Roeckner, E., and Zhang, J.: Cloud microphysics and aerosol indirect effects in the global climate model ECHAM5-HAM, Atmos. Chem. Phys., 7, 3425-3446, doi:10.5194/acp-7-3425-2007, 2007.

McFiggans, G., Artaxo, P., Baltensperger, U., Coe, H., Facchini, M C., Feingold, G., Fuzzi, S., Gysel, M., Laaksonen, A., Lohmann, U., Mentel, T. F., Murphy, D. M., O’Dowd, C. D., Snider, J. R., and Weingartner, E.: The effect of physical and chemical aerosol properties on warm cloud droplet activation, Atmos. Chem. Phys., 6, 2593-2649, doi:10.5194/acp-6-2593-2006, 2006.

Menon, S., Del Genio, A. D., Koch, D., and Tselioudis, G.: GCM Simulations of the Aerosol Indirect Effect: sensitivity to Cloud Parameterization and Aerosol Burden, J. Atmos. Sci., 59, 692713, 2002.

Menon, S., Brenguier, J.-L., Boucher, O., Davison, P., Del Genio, A. D., Feichter, J., Ghan, S., Guibert, S., Liu, X., Lohmann, U., Pawlowska, H., Penner, J. E., Quaas, J., Roberts, D. L., Schuller, L., and Snider, J.: Evaluating aerosol/cloud/radiation process parameterizations with single-column models and Second Aerosol Characterisation Experiment (ACE-2) cloudy column observations, J. Geophys. Res., 108, 4762, doi:10.1029/2003JD003902, 2003.

Meskhidze, N., Nenes, A., Conant, W. C., and Seinfeld, J. H.: Evaluation of a new cloud droplet activation parameterization with in situ data from CRYSTAL-FACE and CSTRIPE, J. Geophys. Res., 110, D03301, doi:10.1029/2004JD005703, 2005.

Ming, Y. and Russell, L. M.: Organic aerosol effects on fog droplet spectra, J. Geophys. Res., 109(D10), 4427, doi:1029/2003JD004427, 2004.

Mozurkewich, M.: Aerosol growth and the condensation coefficient for water: a review, Aerosol Sci. Technol., 5, 223-236, 1986.

Murphy, D. M., Solomon, S.,Portmann, R. W., Rosenlof, K. H., Forster, P. M., and Wong, T.: An observationally based energy balance for the Earth since 1950, J. Geophys. Res., 114, D17107, doi:10.1029/2009JD012105, 2009. 
Novakov, T. and Penner, J. E.: Large contribution of organic aerosols to cloud-condensation-nuclei concentrations, Nature, 365, 823-826, 1993.

Orsini, D. A., Ma, Y., Sullivan, A., Sierau, B., Baumann, K., Weber, R. J.: Refinements to the particle-into-liquid sampler (PILS) for ground and airborne measurements of water soluble aerosol composition, Atmos. Environ. 37, 1243-1259, 2003.

Peng, Y., Lohmann, U., and Leaitch, W. R.: Importance of vertical velocity variations in the cloud droplet nucleation process of marine stratus clouds, J. Geophys. Res., 110, D21213, doi:10.1029/2004JD004922, 2005.

Penner, J. E., Andreae, M., Annegarn, H., Barrie, L., Feichter, J., Hegg, D., Jayaraman, A., Leaitch, R., Murphy, D., Nganga, J. Pitari, G.: Aerosols, their Direct and Indirect Effects in: Climate Change 2001: the Physical Science Basis. Contribution of Working Group I to the Third Assessment Report of the Intergovernmental Panel on Climate Change, edited by: Cambridge Univ. Press, New York, 129-234, 2001.

Penner, J. E., Quaas, J., Storelvmo, T., Takemura, T., Boucher, O., Guo, H., Kirkevåg, A., Kristjánsson, J. E., and Seland, Ø.: Model intercomparison of indirect aerosol effects, Atmos. Chem. Phys., 6, 3391-3405, doi:10.5194/acp-6-3391-2006, 2006.

Petters, M. D. and Kreidenweis, S. M.: A single parameter representation of hygroscopic growth and cloud condensation nucleus activity, Atmos. Chem. Phys., 7, 1961-1971, doi:10.5194/acp-71961-2007, 2007.

Petters, M. D., Prenni, A. J., Kreidenweis, S. M., DeMott, P. J., Matsunaga, A., Lim, Y. B., and Ziemann, P. J.: Chemical aging and the hydrophobic-to-hydrophilic conversion of carbonaceous aerosol, Geophys. Res. Lett., 33, L24806, doi:10.1029/2006GL027249, 2006.

Phinney, L., Leaitch, W. R., Lohmann, U., Boudries, H., ToomSauntry, D., Sharma, S., and Shantz, N.: Characterization of Aerosol Over the Sub-arctic NE Pacific During SERIES, DeepSea Res. II, 53, 2410-2433, 2006.

Pierce, J. R., Chen, K., and Adams, P. J.: Contribution of primary carbonaceous aerosol to cloud condensation nuclei: processes and uncertainties evaluated with a global aerosol microphysics model, Atmos. Chem. Phys., 7, 5447-5466, doi:10.5194/acp-75447-2007, 2007.

Prenni, A. J., Petters, M. D., DeMott, P. J., Kreidenweis, S. M., Ziemann, P. J., Matsunaga, A., and Lim, Y. B.: Cloud droplet activation of secondary organic aerosol, J. Geophys. Res., 112, D10223, doi:10.1029/2006JD007963, 2007.

Pringle, K. J., Carslaw, K. S., Spracklen, D. V., Mann, G. M., and Chipperfield, M. P.: The relationship between aerosol and cloud drop number concentrations in a global aerosol microphysics model, Atmos. Chem. Phys., 9, 4131-4144, doi:10.5194/acp-94131-2009, 2009.

Quaas, J., Ming, Y., Menon, S., Takemura, T., Wang, M., Penner, J. E., Gettelman, A., Lohmann, U., Bellouin, N., Boucher, O., Sayer, A. M., Thomas, G. E., McComiskey, A., Feingold, G., Hoose, C., Kristjánsson, J. E., Liu, X., Balkanski, Y., Donner, L. J., Ginoux, P. A., Stier, P., Grandey, B., Feichter, J., Sednev, I., Bauer, S. E., Koch, D., Grainger, R. G., Kirkevåg, A., Iversen, T., Seland, Ø, Easter, R., Ghan, S. J., Rasch, P. J., Morrison, H., Lamarque, J.-F., Iacono, M. J., Kinne, S., and Schulz, M.: Aerosol indirect effects - general circulation model intercomparison and evaluation with satellite data, Atmos. Chem. Phys.,
9, 8697-8717, doi:10.5194/acp-9-8697-2009, 2009.

Ramanathan, V.: The greenhouse theory of climate change: a test by an inadvertent global experiment, Science, 240, 293-299, 1988.

Rissman, T. A., Nenes, A., and Seinfeld, J. H.: Chemical amplification (or dampening) of the Twomey effect: conditions derived from droplet activation theory, J. Atmos. Sci., 61, 919-930, 2004.

Roberts, G. C., Artaxo, P., Zhou, J., Swietlicki, E., and Andreae, M. O.: Sensitivity of CCN spectra on chemical and physical properties of aerosol: a case study from the Amazon Basin, J. Geophys. Res., 107, 8070, doi:1029/2001JD000583, 2002.

Rolph, G. D.: Real-time Environmental Applications and Display sYstem (READY) Website (http://www.arl.noaa.gov/ready.php). NOAA Air Resources Laboratory, Silver Spring, MD, 2003.

Ruehl, C. R., Chuang, P. Y., and Nenes, A.: How quickly do cloud droplets form on atmospheric particles?, Atmos. Chem. Phys., 8, 1043-1055, doi:10.5194/acp-8-1043-2008, 2008.

Ruehl, C. R., Chuang, P. Y., and Nenes, A.: Distinct CCN activation kinetics above the marine boundary layer along the California coast, Geophys. Res. Lett., 36, L15814, doi:10.1029/2009GL038839, 2009.

Rupakheti, M., Leaitch, W. R., Lohmann, U., Hayden, K., Brickell, P., Lu, G., Li, S.-M., Toom-Sauntry, D., Bottenheim, J. W., Brook, J. R., Vet, R., Jayne, J. T., and Worsnop, D. R.: An Intensive Study of the Size and Composition of Submicron Atmospheric Aerosols at a Rural Site in Ontario, Canada, Aerosol Sci. Tech., 39, 722-736, 2005.

Russell, L. M., Seinfeld, J. H., Flagan, R. C., Ferek, R .J., Hegg, D. A., Hobbs, P. V., Wobrock, W., Flossmann, A., O'Dowd, C., Nielsen, K. E., and Durke, P. A.: Aerosol dynamics in ship tracks, J. Geophys. Res., 104, 31077-31095, 1999.

Shantz, N. C., Leaitch, W. R., and Caffrey, P.: Effect of organics of low solubility on the growth rate of cloud droplets, J. Geophys. Res., 108, 4168-4177, 2003.

Shantz, N. C., Chang, R. Y.-W., Slowik, J. G., Vlasenko, A., Abbatt, J. P. D., and Leaitch, W. R.: Slower CCN growth kinetics of anthropogenic aerosol compared to biogenic aerosol observed at a rural site, Atmos. Chem. Phys., 10, 299-312, doi:10.5194/acp10-299-2010, 2010.

Snider, J. R., Guibert, S., Brenguier, J.-L., and Putaud, J.-P.: Aerosol activation in marine stratocumulus clouds: 2 . Kohler and parcel theory closure studies, J. Geophys. Res., 108(D15), 8629, doi:10.1029/2002JD002692, 2003.

Straub, D. J., Lee, T., and Collett Jr., J. L.: Chemical composition of marine stratocumulus clouds over the eastern Pacific Ocean, J. Geophys. Res., 112, doi:10.1029/2006JD007439, 2007.

Strapp, J. W., Leaitch, W. R., and Liu, P. S. K.: Hydrated and dried aerosol size distribution measurements from the Particle Measuring Systems FSSP-300 probe and the de-iced PCASP-100X probe, J. Atmos. Oceanic Technol., 9, 548-555, 1992.

Targino, A. C., Noone, K. J., Drewnick, F., Schneider, J., Krejci, R., Olivares, G., Hings, S., Borrmann, S.: Microphysical and chemical characteristics of cloud droplet residuals and interstitial particles in continental stratocumulus clouds, Atmos. Res., 86, 225-240, 2007.

Twomey, S.: The Influence of Pollution on the Shortwave Albedo of Clouds, J. Atmos. Sci., 34, 1149-1152, 1977.

Wagner, P.: Aerosol growth by condensation. In Aerosol microphysics II: chemical physics of microparticles, W. H. Marlow editor, Berlin: Springer-Verlag, 129-178, 1982. 
Wang, J., Lee, Y.-N., Daum, P. H., Jayne, J., and Alexander, M. L.: Effects of aerosol organics on cloud condensation nucleus (CCN) concentration and first indirect aerosol effect, Atmos. Chem. Phys., 8, 6325-6339, doi:10.5194/acp-8-6325-2008, 2008.

Wex, H., Petters, M. D., Carrico, C. M., Hallbauer, E., Massling, A., McMeeking, G. R., Poulain, L., Wu, Z., Kreidenweis, S. M., and Stratmann, F.: Towards closing the gap between hygroscopic growth and activation for secondary organic aerosol: Part 1 Evidence from measurements, Atmos. Chem. Phys., 9, 39873997, doi:10.5194/acp-9-3987-2009, 2009.
Zhang, Q., Jimenez, J. L., Canagaratna, M. R., Allan, J. D., Coe, H., Ulbrich, I., Alfarra, M. R., Takami, A., Middlebrook, A. M., Sun, Y. L., Dzepina, K., Dunlea, E., Docherty, K., DeCarlo, P. F., Salcedo, D., Onasch, T., Jayne, T. J., Miyoshi, T., Shimono, A., Hatakeyama, S., Takegawa, N., Kondo, Y., Schneider, J., Drewnick, F., Borrmann, S., Weimer, S., Demerjian, K., Williams, P., Bower, K., Bahreini, R., Cottrell, L., Griffin, R. J., Rautiainen, J., Sun, Y. J., Zhang, Y. M., and Worsnop, D. R.: Ubiquity and dominance of oxygenated species in organic aerosols in anthropogenically-influenced Northern Hemisphere midlatitudes, Geophys. Res. Lett., 34, L13801, doi:1029/2007GL029979, 2007. 